\title{
Review of the family Rivulidae (Cyprinodontiformes, Aplocheiloidei) and a molecular and morphological phylogeny of the annual fish genus Austrolebias Costa 1998
}

\author{
Marcelo Loureiro ${ }^{1}$, Rafael de Sá2, Sebastián W. Serra ${ }^{3}$, Felipe Alonso ${ }^{4,7}$, \\ Luis Esteban Krause Lanés ${ }^{5,6}$, Matheus Vieira Volcan ${ }^{6}$, Pablo Calviño ${ }^{7}$, Dalton Nielsen ${ }^{8}$, \\ Alejandro Duarte ${ }^{9}$ and Graciela Garcia ${ }^{10}$
}

The family Rivulidae is the fourth most diverse clade of Neotropical fishes. Together with some genera of the related African family Nothobranchiidae, many rivulids exhibit a characteristic annual life cycle, with diapausing eggs and delayed embryonic development, which allows them to survive in the challenging seasonal ponds that they inhabit. Rivulidae also includes two species known as the only the self-fertilizing vertebrates and some species with internal fertilization. The first goal of this article is to review the systematics of the family considering phylogenetic relationships and synapomorphies of subfamilial clades, thus unifying information that is dispersed throughout the literature. From this revision, it is clear that phylogenetic relationships within Rivulidae are poorly resolved, especially in one of the large clades that compose it, the subfamily Rivulinae, where conflicting hypotheses of relationships of non-annual and annual genera are evident. The second goal of this work is to present an updated phylogenetic hypothesis (based on mitochondrial, nuclear, and morphological information) for one of the most speciose genus of Rivulidae, Austrolebias. Our results confirm the monophyly of the genus and of some subgeneric clades already diagnosed, but propose new relationships among them and their species composition, particularly in the subgenus Acrolebias.

Keywords: Cynolebiidae, Killifish, Neotropical, Total evidence.

La familia Rivulidae es el cuarto clado más diverso dentro de los peces Neotropicales. Junto con algunos géneros de la familia Nothobranchiidae, muchos rivulidos presentan un característico ciclo de vida anual, con huevos resistentes a la desecación y embriones con diapausas que les permiten sobrevivir en los ambientes estacionales donde habitan. Los Rivulidae presentan también dos especies consideradas como los únicos vertebrados hermafroditas suficientes y algunas especies con inseminación interna. El primer objetivo de este artículo es actualizar la sistemática de la familia considerando las relaciones filogenéticas y las sinapomorfías de los clados que la componen, reuniendo información que se encuentra dispersa en la literatura. De esta revisión surge que las relaciones filogenéticas dentro de Rivulidae están todavía sin resolver, especialmente en uno de los grandes clados que la componen, la subfamilia Rivulinae, donde relaciones conflictivas entre géneros anuales y no anuales son evidentes. El segundo objetivo de este trabajo es presentar una hipótesis filogenética, basada en datos morfológicos, mitocondriales y nucleares, de uno de los géneros más diversos de la familia, el género Austrolebias. Nuestros resultados confirman la monofilia del género y de algunos clados subgenéricos previamente definidos, y propone nuevas relaciones entre ellos, particularmente de las especies del subgénero Acrolebias.

Palabras Clave: Cynolebiidae, Evidencia total, Neotropical, Peces anuales.

\footnotetext{
${ }^{1}$ Facultad de Ciencias Ecología y Evolución, Igua 4225, 11400 Montevideo, MO, Uruguay. marcnagual@gmail.com, (Dhttps://orcid. org/0000-0003-0426-9421 proxy (corresponding author)

${ }^{2}$ Department of Biology, University of Richmond, 28 Westhampton Way, 23173 Richmond, Virginia, USA. rdesa@richmond.edu ${ }^{3}$ Sección Ictiología, Museo Nacional de Historia Natural, 25 de mayo 582, Montevideo, MO, Uruguay. serraelbicho@gmail.com ${ }^{4}$ Instituto de Bio y Geociencias del NOA(IBIGEO)-CONICET, 9 de julio 14, 4405 Rosario de Lerma, Argentina. felipealonso@gmail.com ${ }^{5}$ Laboratório de Fisiologia da Conservação, Programa de Pós Graduação em Zoologia, Pontifícia Universidade Católica do Rio Grande do Sul - PUCRS Av. Ipiranga, 6681 - Partenon, 90619-900 Porto Alegre, RS, Brazil lelanes@gmail.com

${ }^{6}$ Instituto Pró-Pampa, Ictiologia, Rua Gomes Carneiro, 1043, 96010-610 Pelotas, RS, Brazil. matheusvolcan@hotmail.com ${ }^{7}$ Grupo de Investigación y Conservación de Killis (GICK), Calle 122, No 2324, Buenos Aires, Argentina. pablocalvin@yahoo.com.ar ${ }^{8}$ Laboratório de Zoologia, Departamento de Biologia, Universidade de Taubaté, R. Quatro de Março, 432, $12020-270$ Taubaté, SP, Brazil. dnielsen@uol.com.br

${ }^{9}$ Departamento de Ecología y Evolución, Facultad de Ciencias, UDELAR, Montevideo, MO, Uruguay. alejandrodua@gmail.com

${ }^{10}$ Instituto de Biología, Sección Genética Evolutiva, Facultad de Ciencias, UDELAR, Iguá 4225, Montevideo, Uruguay. ggarcia@fcien.edu.uy Departamento de Biología Animal, Facultad de Ciencias, UDELAR, Montevideo, MO, Uruguay. gracielagarci@gmail.com
} 


\section{Introduction}

Killifishes of the family Rivulidae are among the most biologically, ecologically, and evolutionary diverse clades of the Neotropical Ichthyofauna. Rivulids are sexually dimorphic, secondary freshwater fishes, with small adult body sizes (max. SL $200 \mathrm{~mm}$ ), and unique reproductive characteristics among vertebrates. For example, two species of Kryptolebias Costa are the only known self-fertilizing vertebrates (Costa et al., 2010; Avise, Tatarenkov, 2015). Many rivulids have an annual or seasonal life cycle, shared with some genera of the African sister family Nothobranchiidae, which has attracted the attention of researchers in diverse areas (e.g. Arim et al., 2010; Furness et al., 2015; Berois et al., 2016; Casanova-Larrosa et al., 2016; Podrabsky et al., 2016; Reichard, 2016; Thompson et al., 2017). Furthermore, two genera of Cynopoecilini have evolved internal fertilization (Costa et al., 2015). Adaptations associated with an annual life-history include drought resistant eggs and embryonic development with up to three diapauses, phases where development and growth are reversibly suspended (Wourms, 1972; Berois et al., 2016; Podrabsky et al., 2016). Diapause allows fishes to inhabit seasonal ponds that dry out completely during the dry season. Seasonal habitats also impose other challenges including, limited energy, space, and time for sexual maturation and reproduction (Loureiro et al., 2016). Annual rivulids exhibit many adaptations for survival in seasonal habitats, including accelerated growth (Errea, Danulat, 2001; Blazek et al., 2013), specialized trophic strategies (Arim et al., 2010), and reproductive behaviors (Haas, 1976; Belote, Costa, 2003; Garcia et al., 2008; Passos et al., 2013). Despite these many developmental, ecological, and evolutionary challenges, phylogenetic evidence supports multiple origins of annualism within Aplocheiloidei, with six putative independent origins, four of them within Rivulidae (Furness et al., 2015). Seasonal ponds and wetlands also affect the dispersal abilities of annual fishes, potentially favoring endogamy and founder effects, which may facilitate morphological and local genetic variation, differentiation, and eventually speciation.

These attributes of a seasonal life-history strategy have contributed to the diversification of rivulids such that it is the fourth-most diverse family of Neotropical freshwater fishes, currently with 450 valid species (Eschmeyer et al., 2018). Rivulids are, therefore, an excellent model to study biogeographic patterns in the Neotropics at both small (Garcia et al., 2012; Ponce del León et al., 2014) and large spatial scales (Costa, 2010, 2013; Loureiro et al., 2016; Costa et al., 2017a). Nonetheless, these same characteristics elevate their endemism and probability of extinction. There are already four species included in the IUCN Red List as critically endangered and two as endangered (IUCN, 2017), and many more with clear need of conservation (Costa, 2012; Nascimento et al., 2015; Bertaco et al., 2016; Volcan et al., 2016) or included in regional conservation lists (FZBRS, 2014).
Rivulidae vs. Cynolebiidae vs. Aplocheilidae. The name Rivulidae was proposed by Parenti (1981), based on the tribe name Rivulini by Myers (1925). However, van der Laan et al. (2014) questioned the validity of this name since it was preoccupied by a tribe of the Lepidoptera family Noctuidae Grote, 1895. Eschmeyer et al. (2018) noticed this and began to use the name Cynolebiidae in the Catalogue of Fishes, apparently because the next available root comes from Cynolebiatidi (Hoedeman, 1965, in van der Laan et al., 2014). Costa (2016a), suggested the name Aplocheilidae instead, proposing a change in the current status of families of Aplocheiloidei to a subfamilial level. In any case, according to article 55.3.1 of the International Code of Zoological Nomenclature (ICZN, 1999), the definition of the name must wait for a decision from the Commission; until then, we will maintain Rivulidae as the family name of Neotropical aplocheiloids.

Origin, fossils and biogeography. The origin of Rivulidae and other clades of Neotropical freshwater fishes has been assumed to have occurred as a consequence of the separation of Africa and South America in the Upper Cretaceous about 100 million years ago (Costa 2013; Furness et al., 2015). However, using a fossil calibrated tree Costa et al. (2017a), estimated that the split of South American Rivulidae and African Nothobranchiidae could have been occurred around 49 (+/- 12 my) million years ago (early to middle Eocene). This time roughly coincides with Friedman's et al. (2013) hypothesis of the split between Neotropical and African cichlids. However, other hypotheses for the origin of Cichlinae (Genner et al., 2007; McMahan et al., 2013; Matschiner et al., 2017) push back the split from African cichlids back to the late Cretaceous. In all cases, these hypotheses support the idea of transoceanic dispersal for the origin of the New World taxa.

Noteworthy, Altner, Reichenbacher (2015) reported for the first time a fossil of Aplocheiloidei from the upper Miocene Lukeino Formation dated to about six million years ago in the Central Rift Valley of Kenya. Based on osteological and phylogenetic analyses, the authors described a new family, Kenyaichthyidae, which unexpectedly seems related to Rivulidae. However, the authors urge caution when interpreting this finding, considering the relatively young age and a dearth of synapomorphies for Rivulidae, Nothobranchiidae and Aplocheilidae.

Within Rivulidae, several dispersal-vicariance analyses (sensu Ronquist, 1997) by Costa (2010, 2013, 2014a) and a dispersal-extinction-cladogenesis analysis by Costa et al. (2017a), indicate alternative historical scenarios for the modern distribution patterns. These include vicariance events that split ancient (early Oligocene) Brazilian Shield populations, and younger, long-distance dispersal events. Indeed, the dates estimated (middle Miocene) for the divergence between Cynolebias Steindachner and 
Simpsonichthys Carvalho (Cynolebiatinae) coincide with the uplift of the Central Brazilian Plateau (Costa et al., 2017a, 2018). Interestingly, Costa et al. (2018) found that species of Cynolebias and Hypsolebias Costa that inhabit the Catinga in the São Francisco river basin, diversified synchronically during late Miocene to early Pliocene. The authors attributed this diversification to drainage reorganizations caused by continental drift and climate changes. On the other hand, at smaller spatial scales, there is evidence that some annual fishes of Austrolebias Costa (Cynolebiatinae) could be "geodispersed" by river drainage rearrangements connecting the lower Uruguay ecoregion and the Patos ecoregion (Loureiro et al., 2011).

Systematics of Rivulidae. The family Rivulidae was proposed by Parenti (1981) to accommodate the new world aplocheiloids; its monophyly was supported by seven synapomorphies. Subsequent morphological (Costa, 1990, 1998, 2004a; Hertwig, 2008) and molecular (Murphy, Collier, 1997; Hrbek, Larson, 1999; Murphy et al., 1999; Costa, 2013) phylogenetic analyses have supported a monophyletic Rivulidae; although the proposed synapomorphies have changed since Parenti (1981; see Loureiro, de Sá, 2016). In Tab. 1, we show the currently recognized synapomorphies of the family considering the analyses of Costa (2004) and Hertwig (2008). Costa (2004) suggested the existence of three clades within Rivulidae, and although he proposed eight synapomorphies supporting the Rivulinae + Cynolebiasinae sister group relationship, other phylogenetic analyses (combined and molecular) showed conflicting results: a basal polytomy at the origin of these clades (Hrbek, Larson, 1999; Murphy et al., 1999; Costa, 2011a, 2013); a sister group relationship between Kryptolebiasinae + Rivulinae (Vermeulen, Hrbek, 2005; Furness et al., 2015); and a sister group relationship between Kryptolebiasinae + Cynolebiasinae (Pohl et al., 2015; Costa et al., 2017a).

Kryptolebiasinae. This is a clade composed by a single genus with seven valid non-annual species, distributed in the Atlantic coastal basins and estuaries from Florida (USA) to southern Brazil. Three androdioecius species conform a monophyletic unit within the genus (Vermeulen, Hrbek, 2005; Costa et al., 2010) that inhabit mangroves; two of them with clear evidence of self-fertilization (Tatarenkov et al., 2011). Costa (2004) proposed two synapomorphies for Kryptolebias: a dorsally expanded flange on dorsal tip of the autopalatine (Fig. 1a) and a vestigial or absent anterodorsal process of urohyal (Fig. 2a).

Rivulinae. Monophyly of Rivulinae is supported by eight synapomorphies (Costa, 2011a): 1. ventral process of the angulo-articular narrow and triangular shaped (Fig. 3b-c); 2. interhyal bone rudimentary or absent; 3. first epibranchial twisted (Fig. 4a); 4. subdistal process of the second epibranchial absent (Fig. 4a); 5. uncinate process of the third epibranchial forming an angle of about $45-60^{\circ}$ (Fig. 4a); 6. paired process on the first vertebra anteriorly directed; 7. membrane between preopercular laterosensory series and isthmus continuous; 8. E-scales not overlapped. Other combined (Costa, 2013); and molecular phylogenies (Murphy, Collier, 1996; Murphy et al., 1999; Hrbek et al., 2004; Vermeulen, Hrbek, 2005; Furness et al., 2015; Pohl et al., 2015) support the monophyly of Rivulinae.

Tab. 1. Synapomorphies of the family Rivulidae proposed by Costa (2004) and Hertzwig (2008).

\begin{tabular}{l}
\hline Costa (2004) \\
First postcleithrum absent \\
Branchiostegal and opercular membranes united \\
Infraorbital, preopercular, and mandibular canals open \\
Pronounced retrorse process of lateral ethmoid \\
Frontal scales circularly arranged around scale A \\
Ventral process of maxilla bent and directed posteriorly \\
Thin C-shaped preopercle \\
Posterior distal border of distal premaxilla straight \\
Coronoid process of dentary narrow \\
Ventral tip of autopalatine shortened \\
Uncinate process of third epibranchial median \\
Shortened lateral rim of frontal lacrimal very twisted and narrow \\
Minute dermosphenotic \\
Posterior tip of ascending process of premaxilla curved medially \\
Ventral process of angulo-articular median \\
Proximal edge of first hypobranchial bifid \\
Supracleithrum and postcleithrum separated \\
\hline Hertzwig (2008) \\
\hline A1 Adductor mandibulae with a completely separated medial portion \\
A1 Adductor mandibulae inserts caudally on the maxillary \\
A1 Adductor mandibulae origin expanded posteriorly and ventrally at the preopercle \\
Origin of the $m$. intermandibularis expanded posteriorly \\
Presence of a separate foramen mandibulare in the dorsal part of the hyomandibula \\
\hline
\end{tabular}

Plesiolebiasini. This tribe, revised by Costa (2011b), is diagnosed by seven unambiguous synapomorphies: 1 . absence of an anterior expansion on the ventral process of the maxilla; 2. anterior portion of the entopterygoid not overlapping the autopalatine; 3 . anterior retrorse process of lateral ethmoid contacting the main axis of the bone; 4. first two proximal radials of anal fin fused (Fig. 5a); 5 . pelvic bones medially overlapped; 6 . increase in number of neuromasts (between five and seven in the anterior, and four or more in the posterior sections) of supraorbital series; and 7. anal fin with basal region dark gray to black with a row of white to yellow spots. Besides these, Costa (2011b) mentions other synapomorphies that have independently arose in Rachovia maculipinnis Radda (Rachoviini): bony flange on the posterior margin of the autopalatine, dorsal margin of the symplectic with an expansion towards entopterygoid, anterior portion of basihyal narrow, anterior proximal radials of the anal fin widened. 

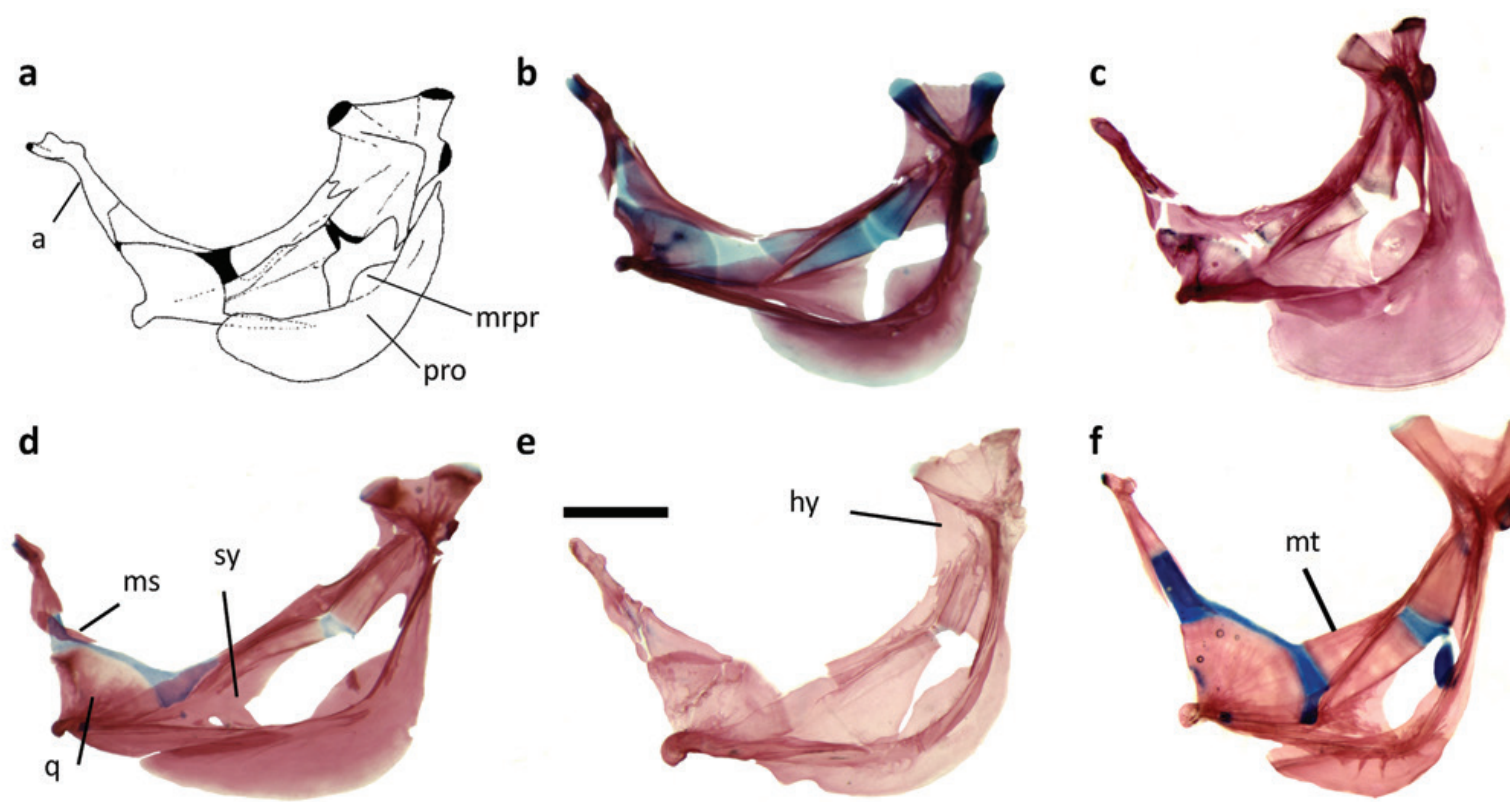

e
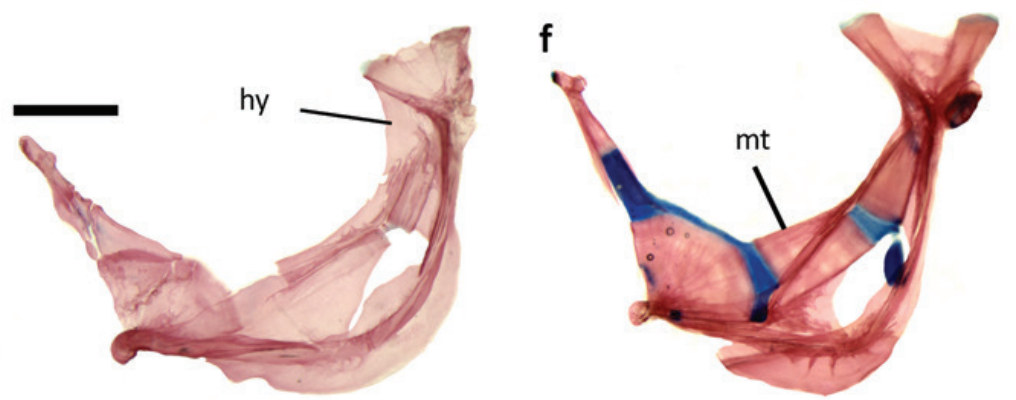

Fig. 1. Suspensorium of a. Kryptolebias caudomarginatus (Seegers) (modified from Costa, 1998), b. Pterolebias longipinnis Garman, c. Papiliolebias bitteri (Costa), d. Cynopoecilus melanotaenia (Reagan), e. Ophthalmolebias constanciae (Myers), f. Austrolebias vazferreirai (Berkenkamp, Etzel, Reichert \& Salvia). "a" = autopalatine, hy = hyomandibula, "mrpr" = median rim of preopercle, "ms" = mesopterygoid, "mt" = metapterygoid, "pro" = preopercle, "q" = quadrate, "sy" = symplectic. Scale bar $=1 \mathrm{~mm}$.

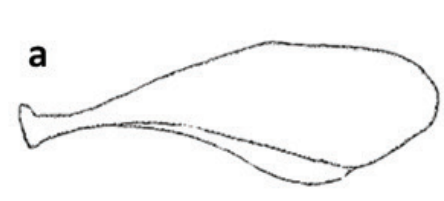

d

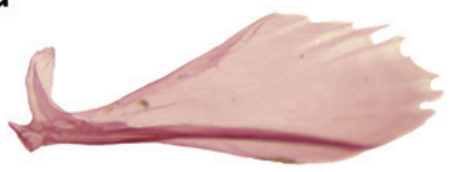

b

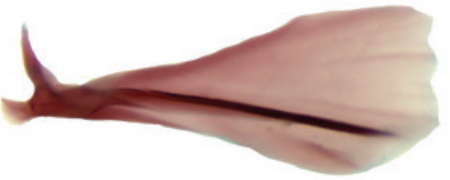

e

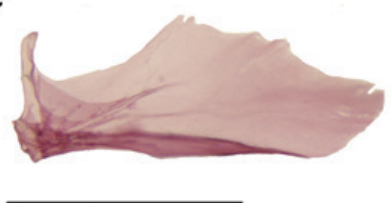

C

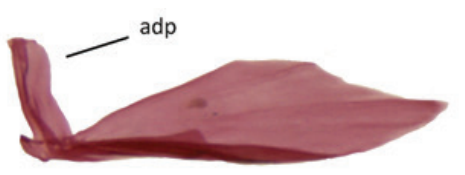

f

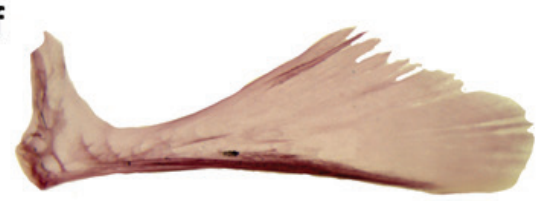

Fig. 2. Urohyal bone of a. Kryptolebias brasiliensis (modified from Costa, 2004), b. Atlantirivulus aff. paranaguensis, c. Cynopoecilus melanotaenia, d. Ophthalmolebias constanciae, e. Austrolebias juanlangi, f. Austrolebias wolterstorff; $\mathbf{a d p}=$ anterodorsal process. Scale bar $=1 \mathrm{~mm}$.

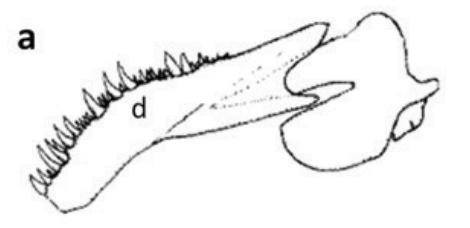

b

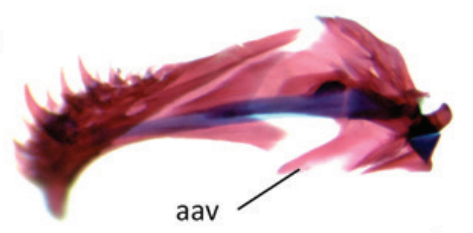

e

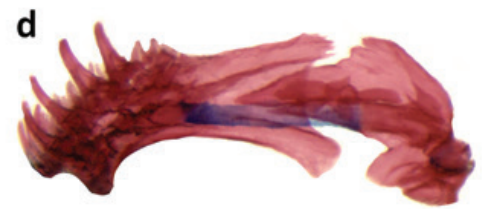

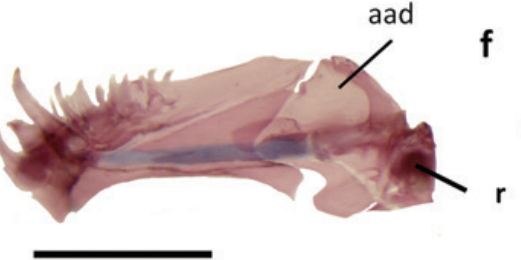

C
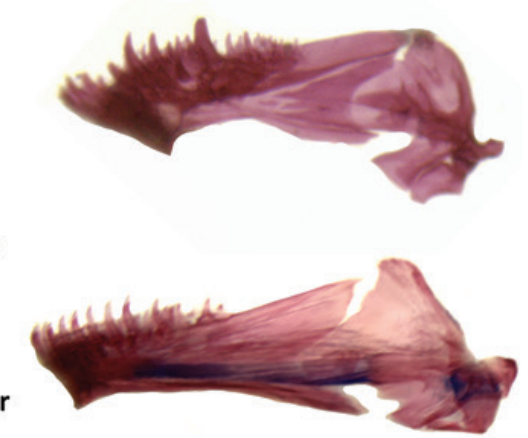

Fig. 3. Lower jaw of a. Kryptolebias brasiliensis (modified from Costa, 2004), b. Pterolebias longipinnis, c. Papiliolebiass bitteri, d. Cynopoecilus melanotaenia, e. Austrolebias juanlangi, f. Austrolebias wolterstorffi; aad = anguloarticular dorsal process, aav $=$ anguloarticular ventral process, $\mathbf{d}=$ dentary, $\mathbf{r}=$ retroarticular. Scale bar $=1 \mathrm{~mm}$. 

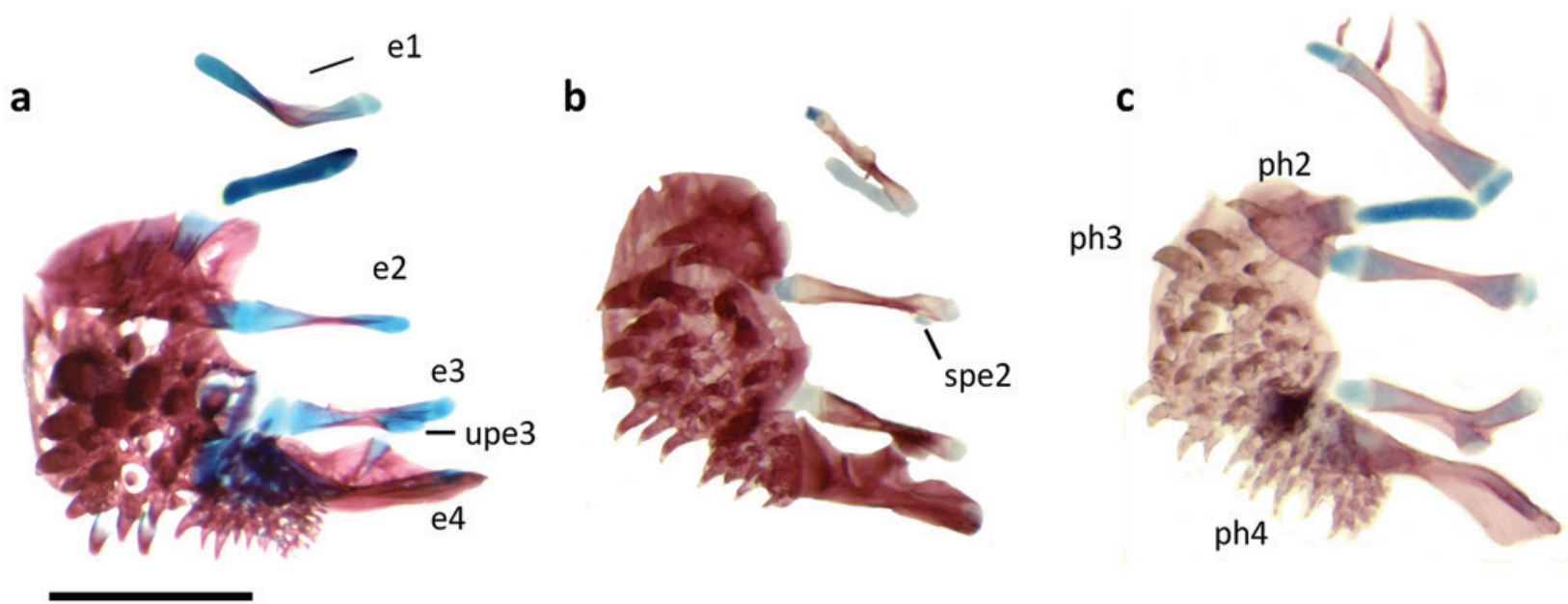

Fig. 4. Ventral view of dorsal gill arches of a. Pterolebias longipinnis, b. Cynopoecilus melanotaenia, c. Austrolebias juanlangi; $\mathbf{e}=$ epibranchial series, $\mathbf{p h}=$ pharyngobranchial series, $\mathbf{s p e} \mathbf{2}=$ epibranchial subdistal process, $\mathbf{u p e} \mathbf{3}=$ uncinate process of epibranchial 3. Scale bar $=1 \mathrm{~mm}$.
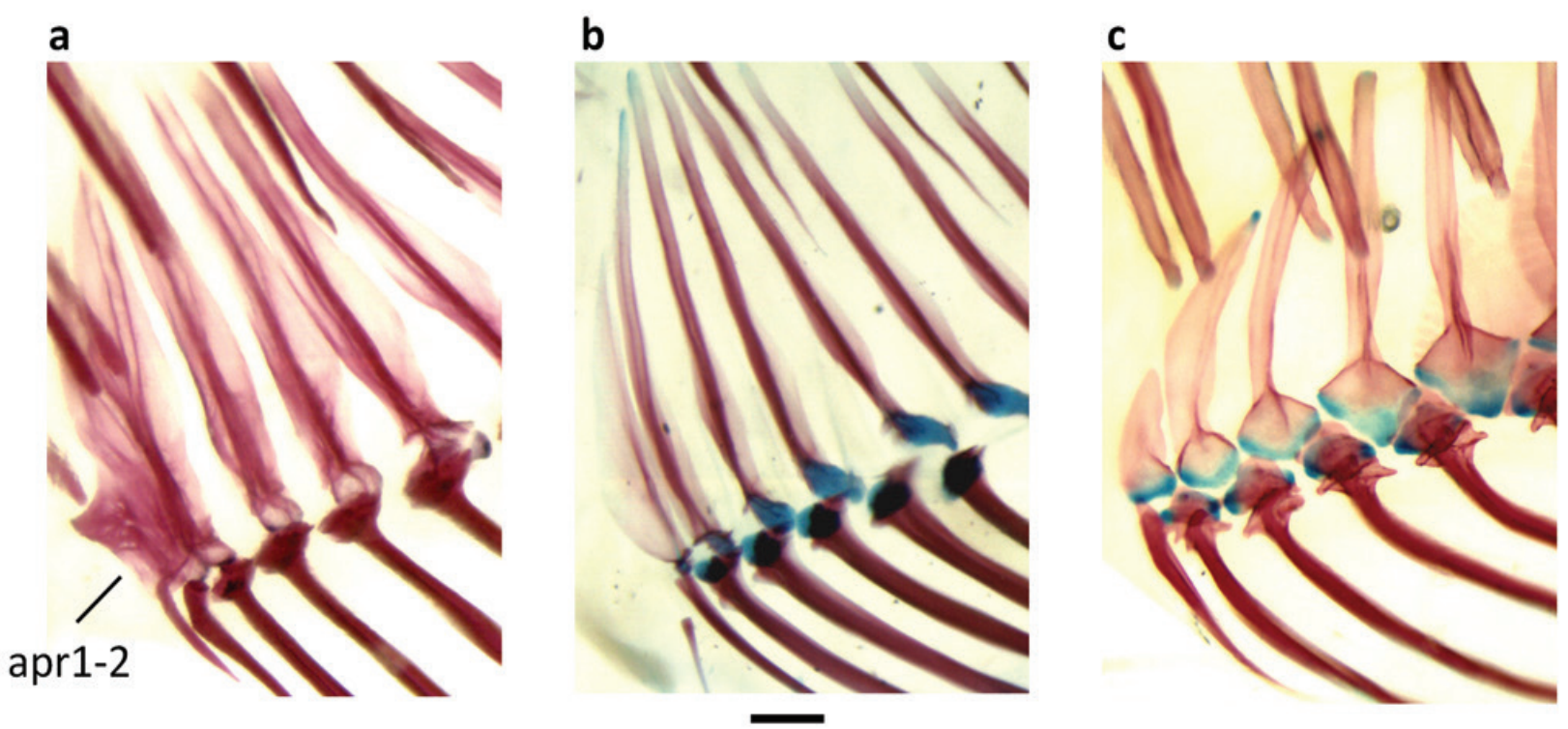

Fig. 5. Anterior section of anal fin of a. Papiliolebias bitteri, b. Pterolebias longipinnis, c. Ophthalmolebias constanciae; apr1-2 $=$ proximal radials fused. Scale bar $=1 \mathrm{~mm}$.

The clade is composed by five small (max. $50 \mathrm{~mm}$ SL) annual genera: Plesiolebias Costa, with eight species distributed in the Araguaia, Canabrava, Tocantins, and Xingú rivers in Brazil and eastern Paraguay; Papiliolebias Costa, with four species distributed in the western chacoan region in the Pilcomayo and Bermejo river basins (La Plata) and Mamoré and Madeira river basin (Amazonas); Maratecoara Costa, with four species distributed in the Tocantins, Xingú, and Canabrava river basins; Stenolebias Costa, with two species distributed in the Paraguay river basin; Pituna Costa, with six species distributed in the Araguaia, Tocantins, Paranaiba, and Canabrava basins. Costa (2011b) phylogenetic analysis supports Plesiolebias as the sister group to the rest of plesiolebiasines, while relationships among these are not clear due to low bootstrap support.
Rachoviini. This tribe, revised by Costa (2014b), is diagnosed by the presence of a prominent urogenital papilla in adult males (Costa 1998), and is well supported by molecular analyses (Hrbek et al., 2004; Hrbek, Taphorn, 2008). Rachoviini is composed by eleven small to large (from 47 to $130 \mathrm{~mm} \mathrm{SL}$ ) annual genera: Moema Costa, with twenty species (including the recently synonymized Aphyolebias Costa, Costa, 2014b) distributed in the rainforest of the Amazon river basin and the Pantanal region in the Paraguay river basin; Trigonectes Myers, with six species distributed in the Paraguay, Guaporé, Mamoré, Araguaia, and Tocantins river basins; Neofundulus Myers, with seven species distributed in the Bermejo, Pilcomayo, Guaporé, Mamoré, and Das Velhas river basins; Pterolebias Garman, with two species distributed in the eastern and southern Amazon and the Paraná-Paraguay 
river basins; Renova Thomerson \& Taphorn, with one species distributed in the Orinoco river basin in Venezuela; Micromoema Costa with one species with similar distribution; Terranatos Taphorn \& Thomerson, with one species with similar distribution; Gnatholebias Costa, with two species distributed in the Orinoco river basin; Llanolebias Hrbek \& Taphorn, with one species in Los Llanos of the Orinoco river basin in Venezuela and Colombia; Rachovia Myers, with four species distributed in the Magdalena, Orinoco (Venezuela and Colombia) river basins and in Lago Maracaibo basin. The very well studied genus Austrofundulus Myers was synonymized to Rachovia by Costa (2014b), based on the paraphyletic nature of the latter, results that were corroborated by Furness et al. (2015). Relationships within rachovines are not confidently resolved, and the clade composed by the genera distributed in the Orinoco, Maracaibo, and Magdalena basins (Renova, Micromoema, Terranatos, Llanolebias, Gnatholebias, Rachovia) is the most supported.

The following taxa have conflicting relationships among one another, and with Plesiolebiasini and Rachoviini, and in the case of Melanorivulini, even its monophyly is questioned (Furness et al., 2015).

Rivulus Poey. It comprises at least two valid species of nonannual fishes (max. $50 \mathrm{~mm}$ SL) distributed in freshwater systems of Cuba (Ponce de León et al., 2014). The genus is distinguished from other non-annual rivulines by the following synapomorphies: all hypurals fused (single plate); neural prezygapophysis of caudal vertebrae rudimentary; fourth ceratobranchial teeth absent; about $50 \%$ of anterior half of caudal fin covered by scales; four neuromasts on the anterior supraorbital series; and black round spot with white margin on the dorsoposterior portion of caudal peduncle in females (Costa, 2011a).

"Rivulus". This taxon is composed by a single non-annual species endemic of the Hispaniola Island, "Rivulus roloffi" Roloff, which according to Hrbek et al. (2004) would be the sister species of all rivulines except Rivulus sensu stricto.

Prorivulus Costa. A monotypic non-annual genus, $P$. auriferus Costa, Lima \& Suzart, from the coastal drainages of northeastern Brazil, is diagnosed by the presence of soft anal fin rays in females, minute urogenital papilla in males, and absence of a dark bar on iris. It has some morphological characteristics similar to Kryptolebias, but other characters more closely align with the rest of Rivulidae. According to the original description it would be the sister taxa of all Rivulidae except Kryptolebias (Costa, 2004b, 2006a). Unfortunately, it has never been included in any subsequent phylogeny or revision, and its position remains uncertain.

Laimosemion Huber. Composed by ca. twenty-nine small to medium-sized species (20-40 mm SL), widely distributed in northwestern South America. The genus lacks synapomorphies, and can be distinguished from other rivulines only by combination of characters, in particular an intense yellow or orange pigmentation of the anal fin in adult females. Monophyly is supported by molecular analyses (Hrbek et al., 2004; Costa 2011a, 2013). This is considered a non-annual genus; however, Furness et al. (2018) have found diapause stages in some species similar to those found in annual species, which could represent intermediates steps in the evolution of the annual life cycle.

Melanorivulini. Costa (2011a) proposed this non-annual tribe based on a single synapomorphy related to the pigmentation pattern of the caudal fin of females. However, molecular analyses suggest that this may be a polyphyletic group (Hrbek et al., 2004), with the sister taxa Anablepsoides Huber and Atlantirivulus Costa more closely related to Plesiolebiasine than to Cynodonichthys Meek and Melanorivulus Costa. Anablepsoides consists of ca. forty-two small to mediumsized species (30-60 mm SL) distributed in the Antilles, small tributaries of northeastern South America, and the Amazon and Orinoco river basins. It is diagnosed by the presence of scales on the whole ventral surface of the head. Atlantirivulus consists of eleven small to medium-sized (25-45 mm SL) species, distributed in coastal rivers of eastern to southern Brazil, diagnosed by disposition in zig-zag of the neuromasts of the infraorbital series and by the presence of a curved ventral process of the angulo-articular. Cynodonichthys consists of ca. twenty-seven medium to large-sized species (50-80 $\mathrm{mm}$ SL) distributed in the Caribbean and Pacific drainages of Central America and northwest South America. This genus lacks synapomorphies. Melanorivulus consists of ca. thirty-seven small to medium-sized species (20-40 mm SL), mainly distributed in central South America including La Plata, São Francisco, and Amazon river basins, and small coastal basins of northeast Brazil and it is diagnosed by the presence of black pigmentation on the margin of the caudal fin and on the distal margin of the dorsal and anal fins in females.

Millerichthys Costa. Monotypic ((M. robustus (Miller \& Hubbs)) small-sized (30 mm SL), annual genus, that is distributed in southern Mexico. The species is diagnosed by the following apomorphies: reduced mesopterygoid; conical and elongate ventral process of posttemporal; long posterior series of supraorbital neuromasts; absence of transverse dark bar crossing the eye; three transverse yellow stripes on the anal fin of males; and black spots along the caudal-fin base of females (Costa, 1998). Its phylogenetic relationship with other Rivulidae remains unclear. Costa (1998), proposed three synapomorphies to support the sister relationship of Millerichthys Costa with Rachoviini: a dorsally pointed preopercle, reduced neural prezygapophyses of caudal vertebrae, and a reduced dark pigmentation in females. However, Costa (2004) hypothesized the genus as the sister taxon of Cynolebiasinae based on three different synapomorphies: mesopterygoid small, posterior tip not contacting metapterygoid; hypurals completely fused; frontal scales in transverse pattern without distinct central scale. 
Cynolebiasinae. The monophyly of this subfamily, composed by small to large-sized annual species, is well supported presenting the following synapomorphies: dorsally positioned dorsomedial process of autopalatine; reduced mesopterygoid; thin $\mathrm{C}$-shaped preopercle with reduced dorsal tip, median rim, and sensory canal (Fig. 1f); elongate epibranchials and interarcual cartilage (Fig. 4c); rounded second hypobranchial (Fig. 6d); absence of teeth in the fourth ceratobranchial; absence of a posteroventral process on the anterior portion of the fourth ceratobranchial; absence of teeth in vomer; thin lachrymal, with narrow lower portion and vestigial sensory canal; absence of dermosphenotic; absence of anterior processes of first vertebra; vestigial or absent neural prezygapophysis of caudal vertebrae (Fig. 7c-d); narrow and anteriorly curved epural and parahypural (Fig. 7c-d); anteriorly placed dorsal fin origin; reduced first proximal anal-fin radial; reduced ossification of medial anal-fin radials; vestigial or absent ventral process of posttemporal; elongate supracleithrum; scale-like pectoral radials (Fig. 8b-c); cylindrical urogenital papilla in males; prominent pocket-like urogenital papilla in females; reduced supraorbital squamation; reduced caudal-fin squamation; continuous supraorbital series of neuromasts; long posterior series of supraorbital neuromasts; minute neuromast on dermosphenotic; and vertical bars on body sides of juveniles (Costa, 1998); Molecular phylogenies support this clade (Murphy et al., 1999; Hrbek, Larson, 1999; Costa, 2013; Furness et al., 2015; Pohl et al., 2015). The two clades that composed the subfamily, Cynopoecilini and Cynolebiasini, are also very well supported by morphological and molecular analyses.

a

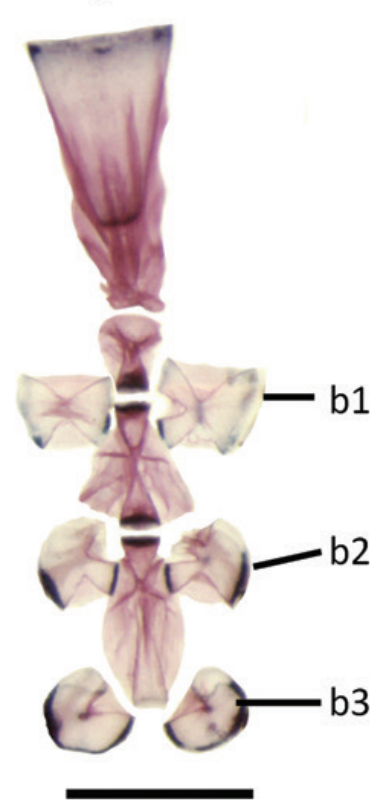

b

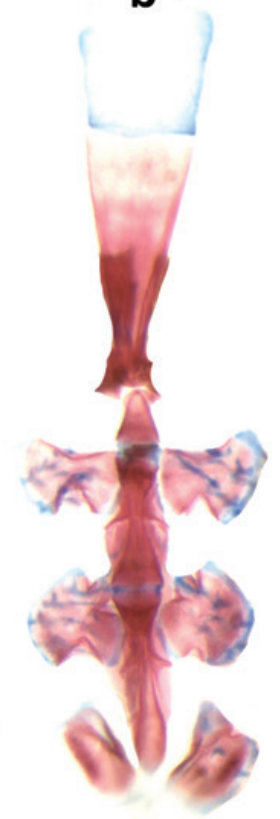

C

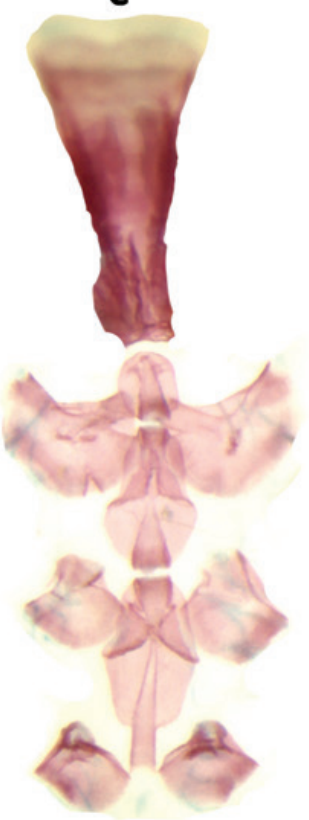

d

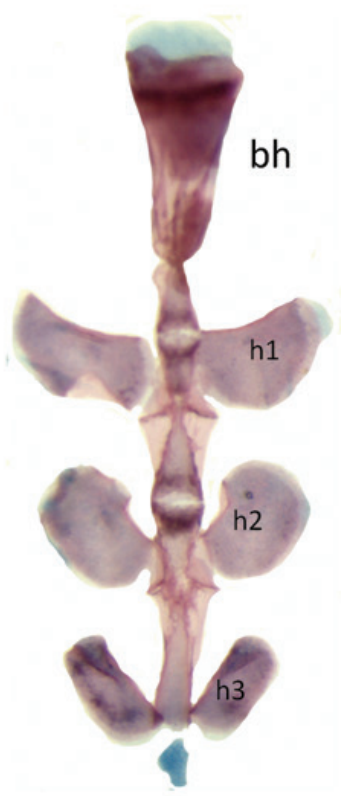

Fig. 6. Dorsal and partial view of ventral gill arches of a. Papiliolebias bitteri, b. Cynopoecilus melanotaenia, c. Ophthalmolebias constanciae, $\mathbf{d}$. Austrolebias juanlangi $\mathbf{b}=$ basibranchial series, $\mathbf{b h}=$ basihyal, $\mathbf{h}=$ hypobranchial series. Scale bar $=1 \mathrm{~mm}$. 

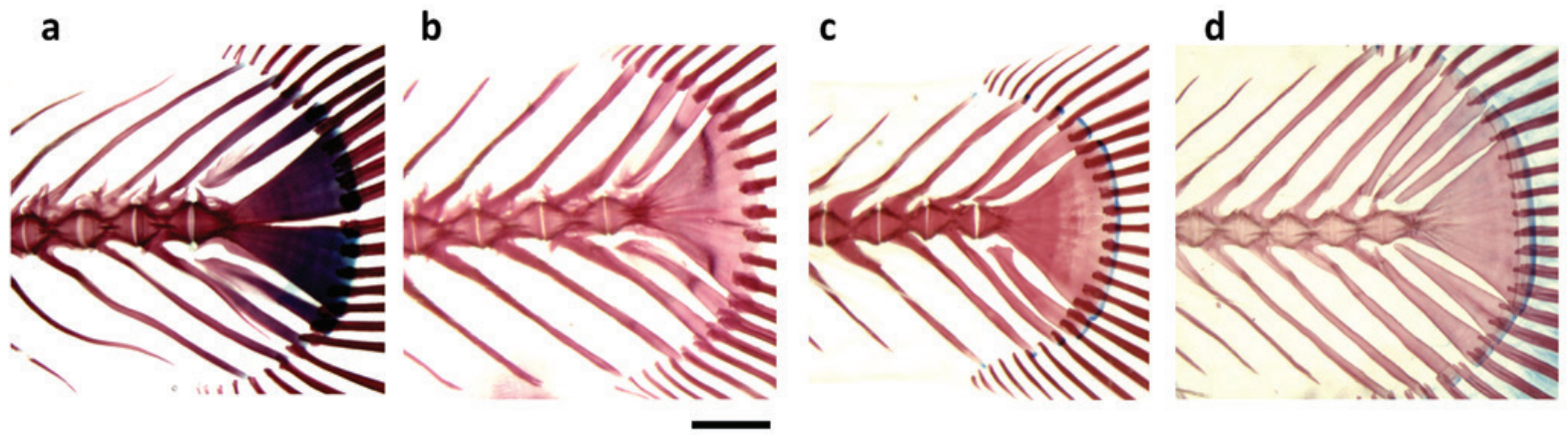

Fig. 7. Caudal skeleton of a. Pterolebias longipinnis, b. Papiliolebias bitteri, c. Cynopoecilus melanotaenia, d. Austrolebias wolterstorffi. Scale bar $=1 \mathrm{~mm}$.
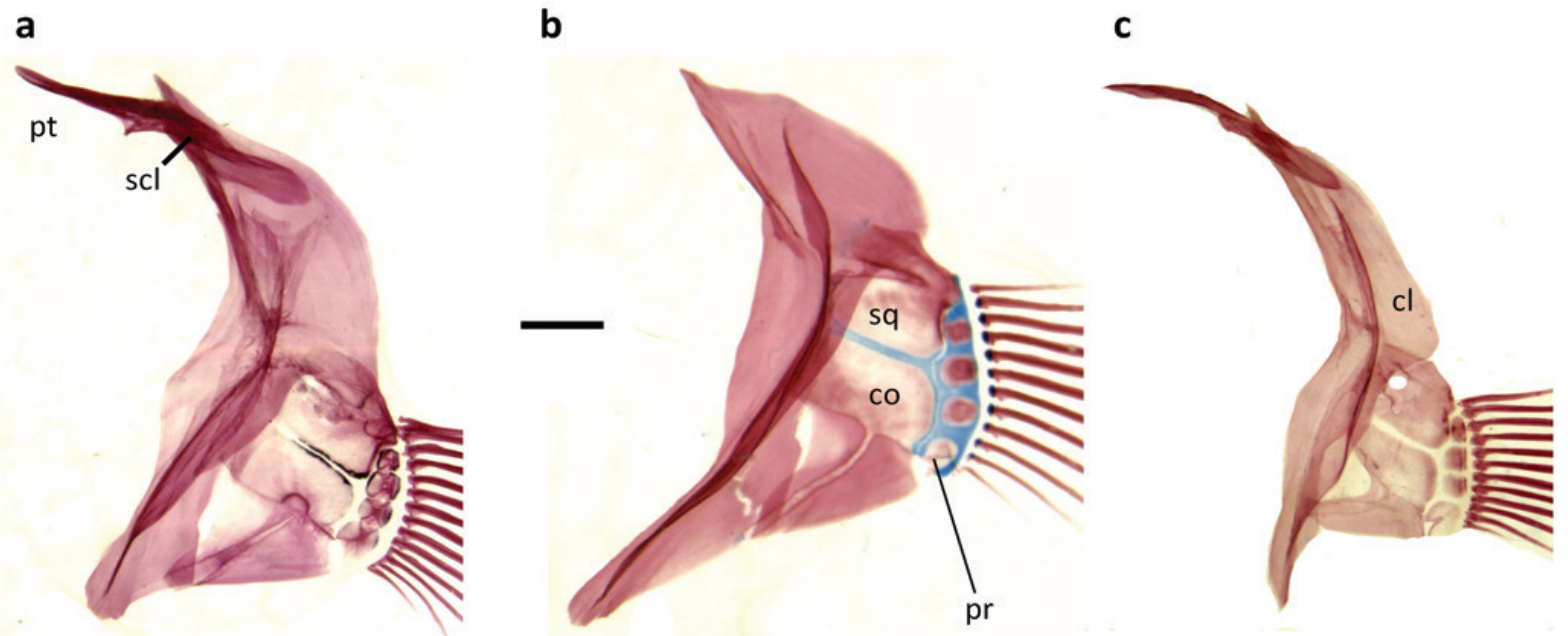

Fig. 8. Pectoral girdle of a. Papiliolebias bitteri, b. Cynopoecilus melanotaenia, c. Ophthalmolebias constanciae; $\mathbf{c l}=$ cleithrum, $\mathbf{c o}=$ coracoid, $\mathbf{p r}=$ pectoral radial, $\mathbf{p t}=$ postemporal, $\mathbf{s c l}=$ supracleithrum, $\mathbf{s q}=$ scapula. Scale bar $=1 \mathrm{~mm}$.

The tribe is composed of seven genera distributed in Atlantic coastal drainages of southeastern and south Brazil and eastern Uruguay (Costa, 2016a): Notholebias Costa, with four small-sized species (max. $30 \mathrm{~mm} \mathrm{SL}$ ) from southeastern Brazil; Mucurilebias, monotypic and small-sized (max. 30 $\mathrm{mm} \mathrm{SL}$ ) genus with similar distribution; Leptolebias, with one small-sized species (max. $29 \mathrm{~mm} \mathrm{SL}$ ) with similar distribution; Leptopanchax, a genus created by Costa (2016a) to fix the paraphyly of Leptolebias found in Costa (2016b), composed of five species with similar distribution; Campellolebias, four small-sized species ( $\max .32 \mathrm{~mm} \mathrm{SL}$ ) with similar distribution and with the development of pseudogonopodium involved in internal fertilization; Cynopoecilus, six small-sized (max. 40 $\mathrm{mm} \mathrm{SL}$ ), distributed in floodplains of the Jacuí river basin and coastal basins of southern Brazil and eastern Uruguay. This genus also presents internal insemination.

Cynolebiasini. This tribe is diagnosed by twelve synapomorphies (Costa, 1998): a broad posteroventral process of dentary; concave anterodorsal margin of opercle; anterior position of anal-fin origin in males; elongated filamentous rays on dorsal and anal fins of males; sexual dimorphism in number of dorsal- and anal fin rays; numerous anal-fin rays in males (19-32); elongated dorsal portion of cleithrum (Fig. 8c); absence of posteroventral flange of cleithrum (Fig. 8c); ventral tip of cleithrum ventrally directed (Fig. 8c); broad anteroventral tip of coracoids; numerous supraorbital neuromasts (12-25); and spawning within substrate (Costa, 1998). Its monophyly is supported also by molecular analyses (Costa et al., 2017a; Furness et al., 2015).

The tribe is composed of eight genera, with small to large adult body sizes ( 30 to $150 \mathrm{~mm} \mathrm{SL}$ ): Nematolebias Costa, with three medium-sized species ( $\max .80 \mathrm{~mm} \mathrm{SL}$ ) distributed in coastal basin of southeastern Brazil; Xenurolebias Costa, with four species with small sizes (max. $30 \mathrm{~mm} \mathrm{SL}$ ) endemic to the Atlantic Forest in southeastern Brazil; Ophthalmolebias Costa, with six species with small sizes (max. $65 \mathrm{~mm} \mathrm{SL}$ ) distributed in eastern Brazil (Costa, 2010); Simpsonichthys, with nine small-sized species (max. $55 \mathrm{~mm} \mathrm{SL}$ ) distributed in the central Brazil Plateau (Costa, 2010); Spectrolebias Costa \& Nielsen, with nine small-sized species (max. $32 \mathrm{~mm} \mathrm{SL}$ ) distributed in the Paraguay, Guaporé, Xingu, Araguaia, and Tocantins river basins (Costa, 2010); Hypsolebias, with fortynine medium-sized species (max. $80 \mathrm{~mm} \mathrm{SL}$ ) distributed in Jequitinhonha, São Francisco, and Urucuia river basins (Costa, 2010); Cynolebias, with twenty two medium to large-sized 
species (50-120 mm SL) distributed in the São Francisco and Urucuia river basins (Costa, 2010); Austrolebias, with fortyeight small to large-sized species (35-150 mm SL) distributed in the La Plata, Patos-Merin, and southwestern Amazon basins (Loureiro, de Sá, 2016; Costa et al., 2017a; Volcan et al., 2017; Alonso et al., 2018).

According to a recent molecular phylogenetic analysis (Costa et al., 2017a), Nematolebias + Xenurolebias are the sister clade of the remaining genera, which relate to each other as follows: Spectrolebias, $((($ Austrolebias,,$(($ Simpsonichthys, Cynolebias), (Opthalmolebias, Hypsolebias))). However, Ponzetto et al. (2016), in a phylogenetic analysis based on one mitochondrial marker, had recently challenged the monophyly of Hypsolebias, with some species more closely related to Ophtlamolebias than to other Hypsolebias.

\section{Morphological and molecular phylogeny of Austrolebias.} Species of the genus Austrolebias were originally included in Cynolebias, that was described just five years earlier by the same author from a single species, C. porosus Steindachner from Pernambuco, northeastern Brazil (Steindachner, 1876). In the first phylogenetic analysis of Cyprinodontiformes, Parenti (1981) provided one synapomorphy to diagnose Cynolebias (caudal fin without scales) and synonymized this genus with several annual genera that had been described during the $20^{\text {th }}$ century (Cynopoecilus Regan, 1912, Leptolebias Myers, 1952, Simpsonichthys, Carvalho, 1959, Campellolebias Vaz-Ferreira \& Sierra, 1974, and Terranatos Taphorn \& Thomerson, 1978). Costa's (1990) phylogenetic analysis of Rivulidae elevated Cynolebias sensu Parenti (1981) to a subfamily level, revalidated those genera previously synonymized, except Simpsonichthys, and rediagnosed Cynolebias based on five synapomorphies.

Costa (1998), in a new phylogenetic analysis of Rivulidae, described Austrolebias and Megalebias Costa (both from La Plata and Patos Merin basins), including some species previously located in Cynolebias. Austrolebias was diagnosed by three synapomorphies and included species previously diagnosed as the " $C$. bellottii Steindachner" species complex (Costa, 1995); Megalebias was also diagnosed based on three synapomorphies and included species previously diagnosed as the "C. elongatus Steindachner" species complex (Costa, 1995). Cynolebias sensu stricto (diagnosed by three synapomorphies) included species previously diagnosed as the "C. porosus" species complex (Costa, 1995), distributed in northeastern Brazil. These three genera were included in the Subtribe Cynolebiatina with Austrolebias as the sister clade of Megalebias + Cynolebias (Costa, 1998). Costa (2002a), changed this relationship and proposed that Cynolebias was the sister genus of Austrolebias + Megalebias. Costa (2006b), considered Megalebias as a synonym of Austrolebias based on a morphological phylogenetic analysis in which Megalebias was nested within Austrolebias. Cynolebiatina was diagnosed by nine synapomorphies (Costa, 1998). However, as was mentioned before, Costa et al. (2017a), proposed Austrolebias as the sister genus of a clade with the following relationships: ((Cynolebias, Simpsonichthys), (Ophthalmolebias, Hypsolebias)).

Monophyly of Austrolebias is supported by three exclusive synapomorphies (Costa, 2006b): absence of scales between the corner of the mouth and anterior portion of the preopercular region and ventral portion of the opercular region, a deep urohyal (Fig. 2e), a dark gray to black infraorbital bar and supraorbital spot; and three synapomorphies independently arose in other cynolebiatines: males with dorsal and anal fins rounded, males with long urogenital papilla, and reduced ventral process of the anguloarticular. However, according to relationships proposed by Costa et al. (2017a), these non-exclusive synapomorphies may represent plesiomorphic states of Cynolebiasini.

Costa (2008b), divided the genus in several subgenera according to the phylogenetic relationships obtained in Costa (2006b): Acantholebias Costa ((type species A. luteoflammulatus (Vaz-Ferreira, Sierra \& Scaglia)), Acrolebias ((type species A. carvalhoi (Myers)), Argolebias ((type species A. nigripinnis (Regan); also known as the "A. alexandri" species group), Austrolebias (type species $A$. bellottii; includes "A. bellotti" + "A. adloffi" species groups), Cypholebias ((type species A. robustus (Günther)), Gymnolebias ((type species A. gymnoventris (Amato)), Megalebias ((type species A. wolterstorff (Ahl)). According to a morphological phylogeny (Costa, 2010) the subgenus Argolebias could be paraphyletic.

Relationships within Austrolebias are still unresolved; conflicting phylogenetic hypotheses have been proposed for this genus using morphological (Costa, 2006b, 2010; Loureiro, 2004) and molecular (mitochondrial) analyses (Garcia et al., 2014). Most subgeneric clades remain stable in species composition; however, relationships among clades and position of some species are still unresolved.

In this study, we performed a phylogenetic analysis of Austrolebias sensu Costa (2006b), using the most complete species sampling to date and a total evidence approach, including morphological, and molecular (mitochondrial and nuclear) data.

\section{Material and Methods}

Specimens analyzed, and tissue samples belong to: Universidade Federal do Rio Grande do Sul (UFRGS), Facultad de Ciencias (ZVCP), Universidade de Taubaté (UNITAU), and Sección Genética Evolutiva (GP, GR). Additional fish were collected on a field trip to Rio Grande do Sul (Brazil) done under the Collection Permit "Portaria No- 909, de 17 de setembro de 2013". For molecular analyses, we extracted total DNA using an extraction kit (Qiagen/ DNeasy Blood \& Tissue Kit) and amplified two segments of mitochondrial genes (16s Ribosomal Unit and Cytochrome b) and two segments of nuclear genes (Recombination activating protein 1, RAG1 and Glycosyltransferase, Glyt) using standard PCR amplification techniques. Primers used were: 16s Ar-L (CGCCTGTTTATCAAAAACAT), Br-H (CCGGTCTGAACTCAGATCACGT) (Palumbi 
et al., 1991); Cytb CB3-H (GGCAAATAGGAARTATCATTC), Gludg-L (TGACTTGAARAACCAYCGTTG) (Palumbi et al. 1991); Rag1-Pachyp-F1 (TGAAAArGCTGTTCGCTTCT) (Pohl et al., 2015), H3405 RAG1ex3 (GCNGAGACTCCTTTGACTCTGTC) (Near et al., 2012); Glyt_F577 (ACATGGTACCAGTATGGCTTTGT), Glyt_R1562 (CCCAAGAGGTTCTTGTT(AG)AAGAT) (Li et al., 2007). Additional (64) sequences were obtained from GenBank. PCR Cycle details were: Cytochrome $b$ : initial denaturalization at $94{ }^{\circ} \mathrm{C} / 3 \mathrm{~min} ; 4$ cycles with denaturalization at $94{ }^{\circ} \mathrm{C} / 1 \mathrm{~min}$, annealing at $45^{\circ} \mathrm{C} / 1 \mathrm{~min}$ and extension at $72^{\circ} \mathrm{C} / 1 \mathrm{~min} ; 29$ cycles with denaturalization at $94^{\circ} \mathrm{C} / 1 \mathrm{~min}$, annealing at $50^{\circ} \mathrm{C} / 1 \mathrm{~min}$ and extension at $72{ }^{\circ} \mathrm{C} / 1 \mathrm{~min}$; and final extension at $72{ }^{\circ} \mathrm{C} / 1 \mathrm{~min}$; $16 \mathrm{~s} R U$ : initial denaturalization at $94{ }^{\circ} \mathrm{C} / 3 \mathrm{~min} ; 4$ cycles with denaturalization at $94{ }^{\circ} \mathrm{C} / 1 \mathrm{~min}$, annealing at $45^{\circ} \mathrm{C} / 1 \mathrm{~min}$ and extension at $72{ }^{\circ} \mathrm{C} / 1 \mathrm{~min} ; 29$ cycles with denaturalization at $94^{\circ} \mathrm{C} / 1 \mathrm{~min}$, annealing at $50{ }^{\circ} \mathrm{C} / 1 \mathrm{~min}$ and extension at $72{ }^{\circ} \mathrm{C} / 1 \mathrm{~min}$; and final extension at $72{ }^{\circ} \mathrm{C} / 1 \mathrm{~min} ; R A G 1$ : initial denaturalization at $95^{\circ} \mathrm{C} / 4 \mathrm{~min} ; 35$ cycles with denaturalization at $95^{\circ} \mathrm{C} / 40 \mathrm{sec}$, annealing at $53^{\circ} \mathrm{C} / 40 \mathrm{sec}$, and extension at $72{ }^{\circ} \mathrm{C} / 90 \mathrm{sec}$; and final extension at 72 ${ }^{\circ} \mathrm{C} / 10 \mathrm{~min}$; Glyt: initial denaturalization at $94{ }^{\circ} \mathrm{C} / 4 \mathrm{~min} ; 35$ cycles with denaturalization at $92^{\circ} \mathrm{C} / 1 \mathrm{~min}$, annealing at 55 ${ }^{\circ} \mathrm{C} / 1 \mathrm{~min}$, and extension at $72{ }^{\circ} \mathrm{C} / 1 \mathrm{~min}$; and final extension at $72{ }^{\circ} \mathrm{C} / 4 \mathrm{~min}$. PCR products were sequenced in Eurofins Genomics Sequencing Data and MACROGEN (Seoul, Korea). Sequences were edited and aligned with MEGA (v. 7.018); nuclear sequences were aligned with Saté (v2.2.7) using the ClustalW2 and MUSCLE options; final edition and concatenation were done with Sequence Matrix. Genbank accession numbers for sequences collected in this study are given in S1. Total and partial number of Bp, variable, and phylogenetic informative sites are shown in Tab. 2.

Tab. 2. Mitochondrial and nuclear markers amplified and used in the phylogenetic analyses. Bp = total number of base pairs amplified; VS = number of variable sites, PS = number of phylogenetic informative sites.

\begin{tabular}{lccc}
\hline Marker & Bp & VS & PS \\
\hline $16 \mathrm{~s}$ & 612 & 377 & 261 \\
Cytb & 996 & 537 & 410 \\
RAG1 & 477 & 130 & 77 \\
GLYT1 & 1016 & 360 & 192 \\
\hline Total & 3101 & 1404 & 940 \\
\hline
\end{tabular}

A 173 character morphological matrix was constructed based on modifications from Costa (2010b ) and Loureiro (2004) (S2, S3, S4).

Forty described, plus one undescribed species of Austrolebias were included in the analyses. We used species of Cynolebiatinae (Cynolebiasini: Cynolebias (2), Simpsonichthys (1), Spectrolebias (2), Hypsolebias (6), Ophthalmolebias (1), Nematolebias (1); Cynopoecilini: Cynopoecilus (1), Campellolebias (1), Leptopanchax (2)), Rivulinae (Pterolebias (1), Papiliolebias (1),
Atlantirivulus (1)), and Kryptolebiatinae (Kryptolebias (1)) as outgroups.

Phylogenetic analyses. Parsimony analyses were implemented in PAUP 4 with the following settings: Heuristic search (stepwise addition, random additional sequence, branch-swapping TBR, Max trees $=1000$, branches collapsed if maximum length is zero, optimization ACCTRAN) and Bootstrap analyses with 1000 replicates. Bayesian analyses were performed with MrBayes (v3.2) with two independent runs of 20 million generations (MCMC) with the following molecular evolution models (estimated with jModelTest 2.0 run on Cypress): 16s $(\mathrm{GTR}+\mathrm{I}+\mathrm{G})$, Cytb $(\mathrm{GTR}+\mathrm{I}+\mathrm{G})$, Rag1 (TPM3+I+G), Glyt $(\mathrm{TVM}+\mathrm{I}+\mathrm{G})$; the $\mathrm{MKV}$ evolution model was used for morphological characters. Tracer v1.6 was used to check for convergence of parameter estimates; (ESS) values of all parameters above 200 . The first $25 \%$ of each run was discarded as burn-in. Phylogenetic analyses were performed on the concatenated sequences alone and combined with morphological characters.

\section{Results}

Concatenated sequences. Parsimony and Bayesian analyses of molecular data failed to recover a monophyletic Austrolebias (Figs. 9, 10). Parsimony yielded 1,325 trees with 5,255 steps, and the node supporting Austrolebias had low support (Bootstrap value $<80 \%$ ). Considering that low support also appeared in more inclusive and nested nodes, the resulting topology can be interpreted as a polytomy with seven branches: 1. Ophthalmolebias constanciae, 2. a clade composed by Simpsonichthys, Spectrolebias, and Hypsolebias, 3. Cynolebias, 4. A. nigripinnis, 5. the "A. alexandri" species group, 6. the clade conformed by $A$. wichi and $A$. varzae, and 7. remaining Austrolebias species. Within this latter clade another polytomy resulted: A. wolterstorff, the remaining "A. elongatus" species group, the clade $A$. jaegari and $A$. gymnoventris, the " $A$. bellottii" species group, the clade $A$. luteoflammulatus $+A$. quirogai, the " $A$. robustus" species group, and the "A. adloffi" species group (including $A$. araucarianus).

Bayesian analysis resulted in $A$. nigripinnis as the sister taxon of the clade conformed by Cynolebias, the clade Simpsonichthys, Spectrolebias, and Hypsolebias, and the remaining Austrolebias. Within these, the topology recovered was ( $A$. wichi, $A$ varzeae) (the "A. alexandri" species group, (( A. jaegari, A. gymnoventris) (the $A$. bellottii species group)) (part of the "A. elongatus" species group), (A. wolterstorffi), ((A. luteoflammulatus, A quirogai) ("A. robustus" species group, " $A$. adloffi" species group, including A. araucarianus)))).

Other interesting results come from within the species groups. In the " $A$. alexandri" species group, species from the Jacuí river basin (A. litzi, A. paucisquama, A. cyaneus) composed a clade. The enigmatic $A$. toba, is the sister species to the clade $A$. ibicuiensis, A. alexandri. In both 
analyses, $A$. periodicus appears as a polyphyletic entity, with some specimens more related to $A$. affinis and others to $A$. duraznensis and $A$. juanlangi. In the " $A$. robustus" species group, the topology recovered questions the validity of $A$. vazferreirai, which could be a junior synonym of $A$. cinereus, and the validity of $A$. nonoiuliensis, which could be a junior synonym of $A$. robustus.
In the "A. adloffi" species group, the analyses show that $A$. nachtigalli from Arroio Grande could be a different entity from those from Yaguarón river, which are more closely related to $A$. reicherti. In the parsimony analysis, $A$. araucarianus is nested in this group, however the Bayesian analysis suggests this species is the sister to the remaining species excluding $A$. viarius.

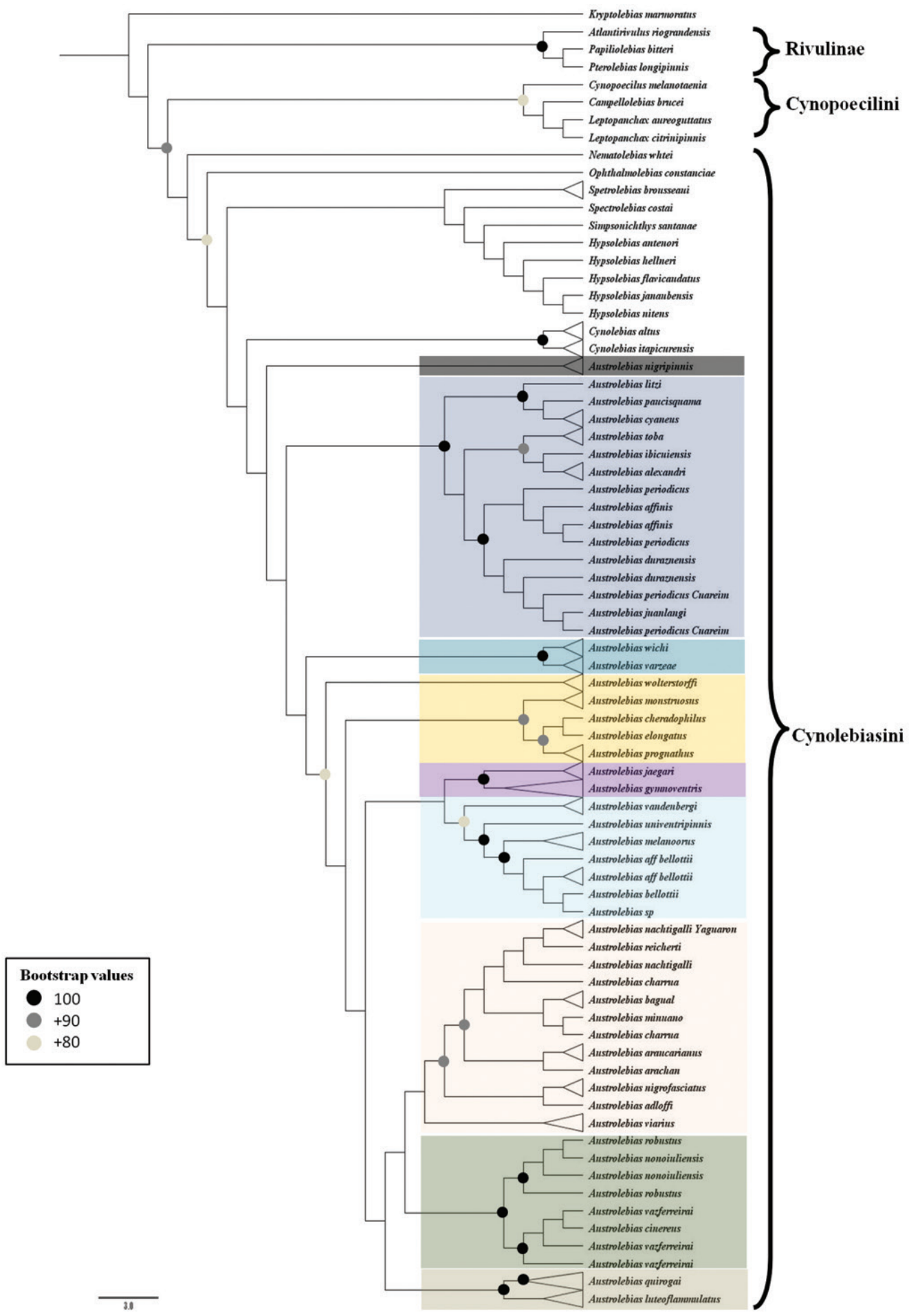

Fig. 9. Maximun parsinony phylogenetic tree of Austrolebias, based on the molecular markers (ribosomal unit 16s, Citochrome b, RAG1, Glyt). Colored areas same as Fig. 12. 


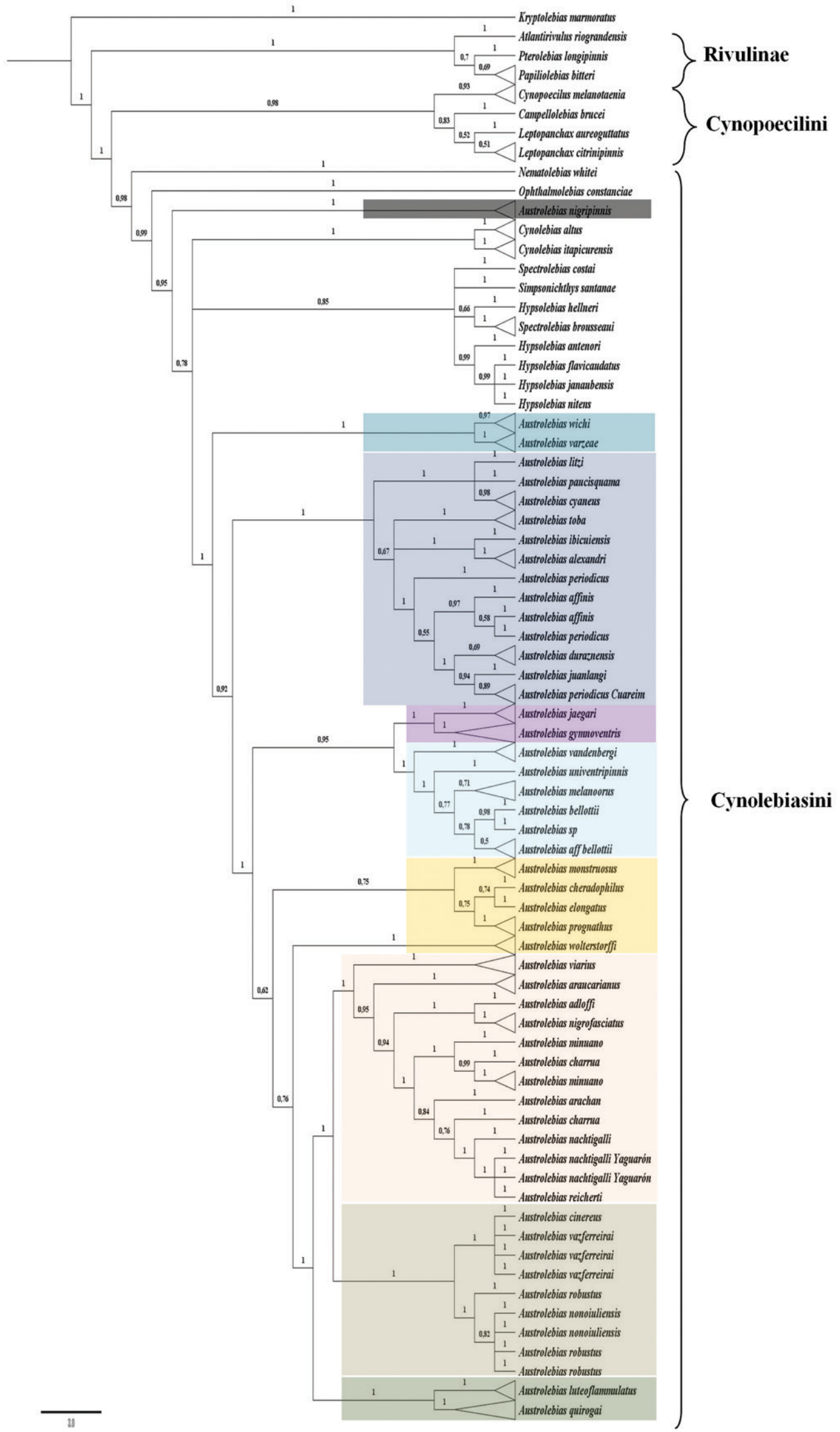

Fig. 10. Bayesian phylogenetic tree of Austrolebias, based on the molecular markers (ribosomal unit 16s, Cytochrome b, RAG1, Glyt). Values above branches are posterior probabilities. Colored areas same as Fig. 12. 
Total evidence (Figs. 11, 12). Both approaches (Parsimony and Bayesian) supported a monophyletic Austrolebias, with A. nigripinnis as the sister taxon to the remaining species. Due to the low support of many nodes, Parsimony analysis did not resolve relationships among species groups which collapsed in a basal polytomy. Bayesian analysis resulted in better support for some nodes, but also could not resolve relationships among several species groups within the genus.

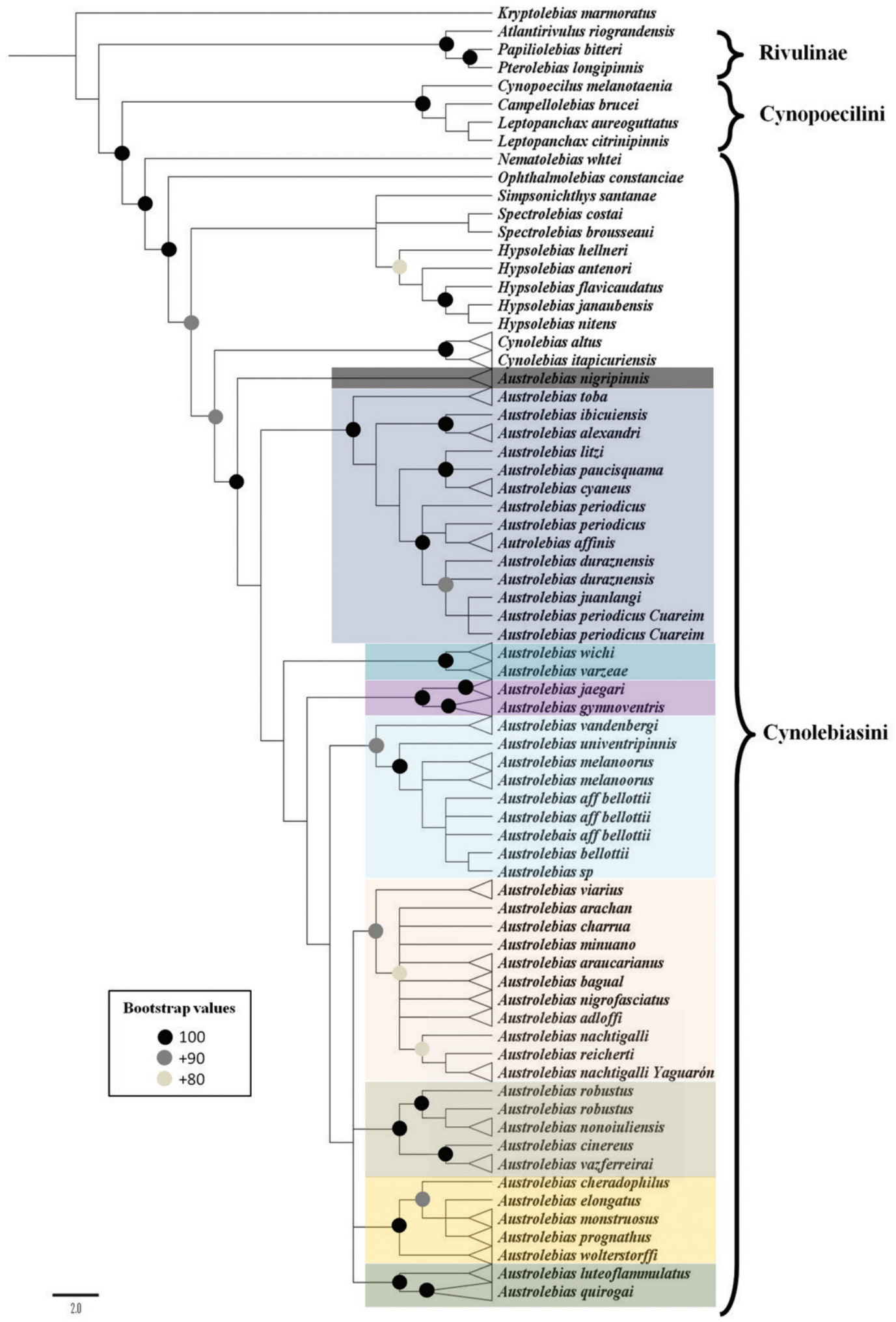

Fig. 11. Maximun parsimony phylogenetic tree of Austrolebias, based on molecular (ribosomal unit 16s, Cytochrome b, RAG1, Glyt) and morphological characters. Colored areas same as Fig. 12. 


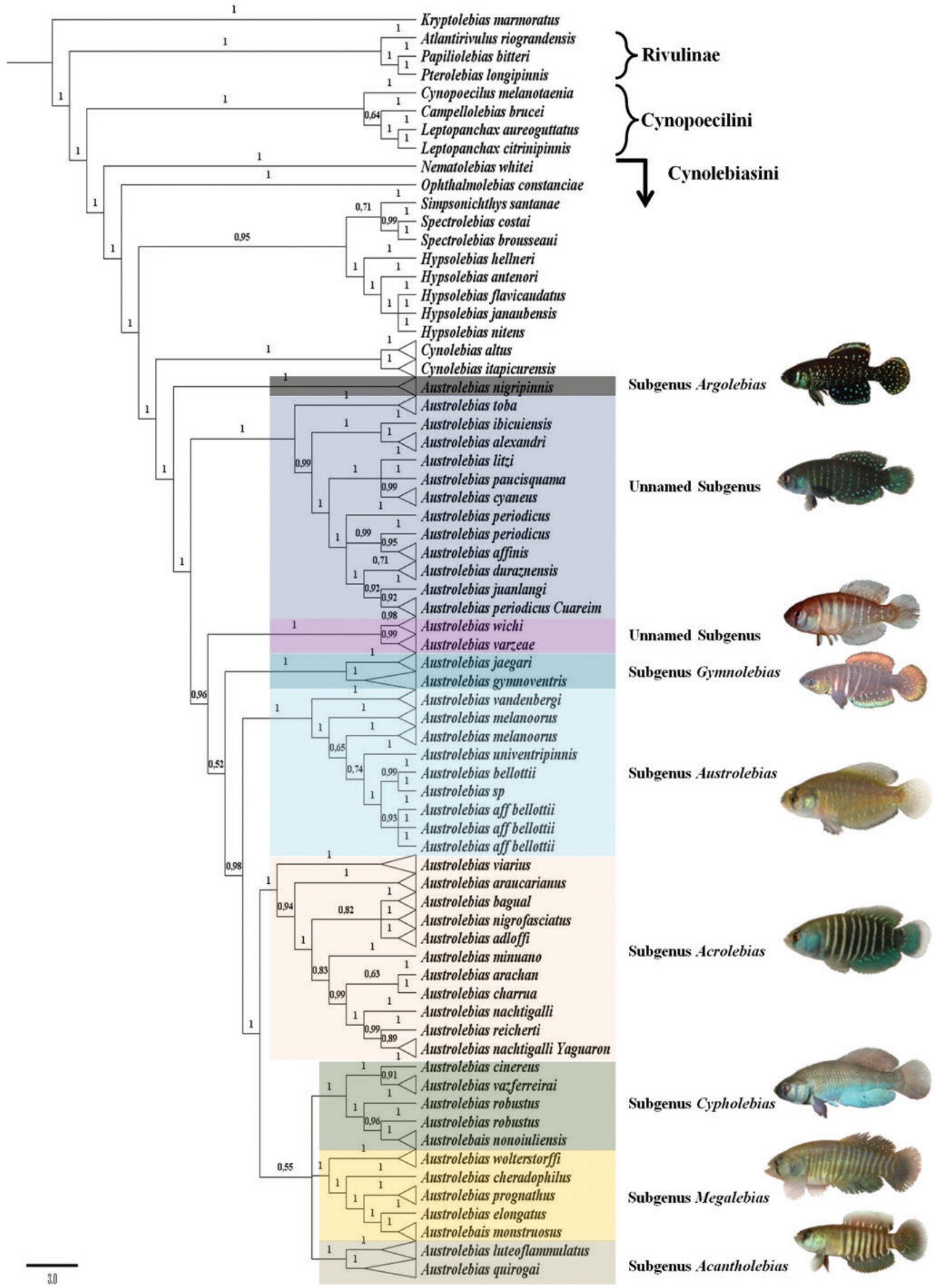

Fig. 12. Bayesian phylogenetic tree of Austrolebias, based on molecular (ribosomal unit 16s, Cytochrome b, RAG1, Glyt) and morphological characters. Values above branches are posterior probabilities. 
The general topology of the total evidence analysis was similar to the molecular analyses, however, some noteworthy differences could be observed. Within the "A. alexandri" species group, A. toba was found to be the sister taxon of the remaining species. The polytomy within the genus was composed by three clades: (A. wichi, A. varzeae), (A. jaegari, A. gymnoventris), and the remaining species. Within the latter, the "A. bellottii" species group is the sister taxon of a clade composed by the "A. adloff" species group, A. luteoflammulatus + A. quirogai, the "A. robustus" species group, and the "A. elongatus" species group. Bayesian analysis supports the position of $A$. araucarianus as the sister species of the "A. adloffi" species group (except $A$. viarius) and grouped species from the Laguna dos Patos in a single clade and species from the Laguna Merin as its sister taxon.

\section{Discussion}

Although monophyly of the genus Austrolebias was supported in most analyses, the position of $A$. nigripinnis in the analyses of the genetic markers generates a doubt about the generic identity of this species. Previous morphological (Costa, 2010) and morphological plus cytochrome b (Alonso et al., 2018) phylogenetic analyses, had already proposed $A$. nigripinnis as the sister taxon of the remaining Austrolebias. The strong support of this hypothesis in the total evidence analyses of this study confirms that this species may have originated from the earliest split of the genus. The affinity of this species to other Cynolebiasini, and its changing position in the tree depending on the genetic marker considered (data not shown) may be the result of incomplete lineage sorting, retention of ancestral polymorphisms (Garcia et al., 2009), or the effect of introgressive events; events that have already been proposed to occur in the genus (Garcia, 2006). However, more detailed analyses with more genetic data and more populations sampling will be needed to address this hypothesis.

In order to avoid paraphyly, A. nigripinnis should not be considered as part of the "A. alexandri" species group and should be considered the only species in the subgenus Argolebias. Unfortunately, sequences of A. paranaensis, a species very similar to $A$. nigripinnis (Costa 2006b), were not available for this study and its phylogenetic position remains unknown. Consequently, the remaining species of the " $A$. alexandri" species group lose its single synapomorphy of dark gray pectoral fins with bright blue iridescence in males (Costa, 2006), and can only be diagnosed by combination of characters. This study confirms the position of $A$. toba within this species group as suggested by Calviño (2005), possibly as the sister taxon of the remaining species, and the position of A. paucisquama (Ferrer et al., 2008), which is closely related to the other species of the group distributed in the Jacuí river basin (Patos drainage). In all analyses, the monophyly of $A$. periodicus is questioned, suggesting that it could be a junior synonym of $A$. affinis, a species with unclear diagnostic characters (Costa, 2002b, 2006b). Furthermore, populations of the upper Cuareim River (middle Uruguay basin), originally described as A. luzardoi (Perujo et al., 2005), and later synonymized with $A$. periodicus (Costa, 2006b), seem to be more closely related to $A$. duraznensis and A. juanlangi, species from the Negro river basin. Analyses at the species and population levels will eventually elucidate the identity and validity of these taxa. As mentioned by Loureiro et al. (2011), this clade presents a distribution pattern that suggests dynamic interconnections among basins of the lower Uruguay (Ibicuy and Negro river basins) and the Patos (Jacuí, Yaguarón, and Tacuarí river basins) ecoregions. The recent description of a species of this group (Volcan et al., 2017, not included in these analyses) from the Camaquã river basin (Patos Ecoregion), completes this scenario. In this sense, results of these analyses show a strong biogeographic relationship between the upper and middle Ibicuí and the upper Negro river basins. This pattern is similar to that of other freshwater fish taxa, such as the cichlid Gymnogeophagus (Malabarba et al., 2015). Interestingly, the upper parts of both basins present stream configurations such as elbows (see Bishop, 1995) that suggest past river capture events.

Austrolebias wichi is a species recently described and closely related to A. patriciae (Alonso et al., 2018). The position of $A$. patriciae has always been difficult to resolve. Costa (2006b) proposed it as the sister taxon of the clade composed by the "A. bellottii" + "A. adloffi" species groups. Costa (2010) included it as the sister taxa of the "A. bellottii" species group. A mitochondrial analysis placed it as the sister taxon of the "A. alexandri" species group (Garcia et al., 2014). In this study, we recovered this species as closely related to $A$. varzeae, a morphologically similar species that inhabits the upper Uruguay river basin (Alonso et al., 2018). This clade presents one synapomorphy: males with dark grey to bluish bands anterior to dorsal fin origin.

Costa (2014c) included A. araucarianus in the subgenus Acrolebias, originally composed by $A$. varzeae and $A$. carvalhoi (Costa, 2008b). According to all our analysis, $A$. araucarianus is closely related to the "A. adloffi" species group, and although we did not include $A$. carvalhoi in this work, the similarity of this species with $A$. araucarianus (Costa, 2014c) suggests their close phylogenetic affinity. If this is confirmed, the subgenus Acrolebias should exclude $A$. varzeae and include the "A. adloffi" species group.

These results show close relationships among species distributed in highlands of the Paraná (A. araucarianus), upper Negro (A. arachan) and Patos ecoregions ("A. adloffi" species group), conforming a clade with a disjunct distribution (Fig. 13). These spatial gaps in the distribution of members of this clade suggest the possibility of extinction in a large region located in the southwestern tip of the Brazilian shield. Such events could have been triggered by the peripheral depression that occurred from early to middle Miocene in this area (Ab'Saber, 1969). Splitting of species from Patos and Merin lagoons basins may also be associated with sea level changes that have occurred in the last four hundred thousand years (Sprechmann, 1978). 


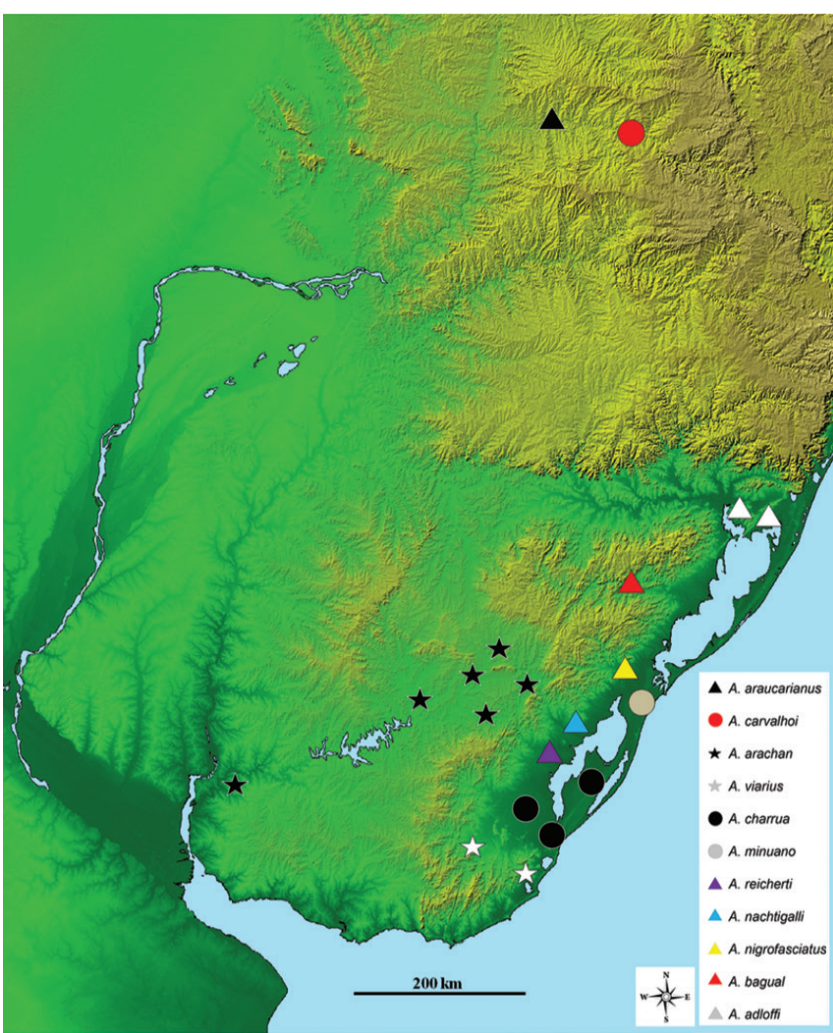

Fig. 13. Distribution map of the subgenus Acrolebias according to present phylogenetic analyses. Red dot $=A$. carvalhoi; Black triangle $=A$. araucarianus; Black star $=$ A. arachan; White star $=A$. viarius; Black dot $=A$. charrua; White $\operatorname{dot}=A$. minuano; Purple triangle $=A$. reicherti; Light blue triangle $=A$. nachtigalli; Yellow triangle $=A$. nigrofasciatus; Red triangle $=A$. bagual; White triangle $=$ A. adloffi. Map modified from Shuttle Radar Topography Mission (SRTM), Courtesy NASA/JPL-Caltech.

Our analysis also questions the validity of the current limits of $A$. nachtigalli; populations of the northern bank of the Yaguarón river basin are more closely related to $A$. reicherti, distributed in the southern bank of the same river and in Tacuarí river basin, than to populations of $A$. nachtigalli from Arroio Grande basin (a northern tributary of Laguna Merin in Rio Grande do Sul). Loureiro, García (2008) reported no distinguishing characters between these species. Unfortunately, Costa's et al. (2017b) cytochrome b phylogenetic analysis of the "A. adloffi" species group did not includ sequences from the Yaguarón river basin. This analysis also suggested that $A$. minuano and $A$. charrua could represent a single species. Our analyses could not resolve the position of $A$. minuano, which, depending on the approach, related this species to a clade composed by $A$. charrua and $A$. arachan, or to $A$. adloffi. As was proposed for A. nigripinnis, changes in topologies according to the genetic marker suggest possible past events of hybridization or introgression, phenomena that were hypothesized by García (2006) to have influenced the evolution of the " $A$. adloffi" species group.
The absence or reduction of scales in the opercular and abdominal region (Loureiro et al., 2011) and cytochrome b phylogenetic analyses (García et al., 2014) suggested that the clade composed by A. gymnoventris and A. jaegari may be closely related to $A$. luteoflamulatus and $A$. quirogai. In this study, we show that these pairs of species may be distantly related, and that reduction of scales (also present in A. cheradophilus and A. prognathus) may have occurred independently.

The polytomy that joins the "A. luteoflammulatus" species group, the "A. robustus" species group, and the "A. elongatus" species group, could be a "soft" polytomy which needs to be solved with more data (especially molecular data). Alternatively, this could be a "hard" polytomy, the result of rapid simultaneous speciation of ancestors of these clades, a phenomenon which has been proposed as probable for this genus by Garcia et al. (2014). Furthermore, the "A. elongatus" species group presents a large set of synapomorphic characters probably associated with an increase in body size (many of these traits arose independently in the "giant" Cynolebias), and large prey acquisition. These features could indicate an ecological process of rapid phenotypic differentiation and speciation. Species of the "A. elongatus" group are restricted to seasonal environments associated with large wetlands or river floodplains of the Bermejo, La Plata estuary, lower Uruguay, and Patos-Merin basins, suggesting ecological connections among these areas possibly associated with sea level retractions during the Pleistocene. The most recent of these putative connections may have occurred ca. 18 thousand years ago when the Paraná River flowed directly to the Atlantic Ocean (Ayup-Zouain, 2006).

Despite the large amount of systematic work done in the family, especially by W. Costa, more work is still needed to reach a stable phylogenetic hypothesis for Rivulidae. At the subfamilial level, relationships among the Kryptolebiasinae, Rivulinae, and Cynolebiasinae remain unclear, and at the generic level, relationships within Rivulinae and Cynolebiasini are also incompletely resolved. Problems arise from the great morphological similarity among species and even genera, often diagnosed mainly by coloration patterns alone; and the great intraspecific variability, which has not even been incorporated in analyses of many taxa. Going forward, we must increase molecular sampling and analyses with conservative markers and variable markers to refine the species limits and relationships among closely related taxa. Morphological work also needs to be expanded to the analysis of intraspecific variability, since many diagnostic characters for species and genera rely on very few specimens, and the polymorphic nature of many species remains obscure.

Comparative material examined. Lots examined belong to: Facultad de Ciencias, Montevideo (ZVC-P); Museu de Ciências e Tecnologia da PUCRS, Pontifícia Universidade Católica do Rio Grande do Sul (MCP); National Academy of Sciences 
of Philadelphia (ANSP); Museum of Zoology, University of Michigan (UMMZ); Muséum d'histoire naturelle de Genève (MHNG); C\&S = Cleared and Stained. Austrolebias adloffi: Brazil: ANSP 168844, 6, 32.1-42.0 mm SL., ZVC-P 724, 25, 23.2-37.1 mm SL (8 C\&S), ZVC-P 747, 25, 22.1-42.2 mm SL; ZVC-P 854, 16, 24.2-35.2 mm SL; ZVC-P 855, 13, 32.1-33.0 mm SL; MCP 10288, 12, 30.1-33.2 mm SL; MCP 15040, 2, 32.2-37.2 mm SL; MCP 10933, 20, 30.1-31.4 mm SL; UMMZ 168844, 4, 30.1-41.2 mm SL; UMMZ 181681, 16, 30.1-33.0 mm SL; UMMZ 181682, 22, 24.1-30.2 mm SL (2C\&S). Austrolebias affinis: Uruguay. ZVC-P 4300, 4, 23.6-32.0 mm SL; ZVC-P 4301, 6, 22.1-25.0 mm SL, ZVC-P 4302, 10, 32.1-34.0 mm SL; ZVC-P 4305, 4, 35.4-38.0 mm SL; ZVC-P 4306, 6, 23.5-34.6 mm SL; ZVC-P 4308, 10, 31.2-33.1 mm SL.Austrolebias alexandri: Uruguay: ZVC-P 2760, 2, 31.2-36.0 mm SL (2C\&S). Austrolebias arachan: ZVC-P 4336 (holotype), 1, 37.8 mm SL; ZVC-P 4574, 14, 32.4-40.2 mm SL (2 C\&S); ZVC-P 4314, 3, 35.4-42.0 mm SL; ZVC-P 4317, 8, 34.1-42.0 mm SL (4 C\&S); ZVC-P 4332, 15, 37.1-42.2 mm SL; ZVC-P 4333, 19, 35.4-41.0 mm SL (8 C\&S); ZVC-P 4329, 4, 40.0-42.2 mm SL (4 C\&S); ZVC-P 4331, 21, 31.5-39.8 mm SL (3 C\&S). Austrolebias bellottii: Argentina: UMMZ 181683, 3, 42.1-45.0 mm SL (3C\&S); ZVC-P 708, 10, 38.9-41.2 mm SL; ZVC-P 712, 1, 50.1 mm SL; ZVC-P 715, 1, 45.6 mm SL; ZVC-P 716, 3, 38.7-45.1 mm SL; ZVC-P 954, 5, 35.6$45.1 \mathrm{~mm}$ SL. Austrolebias aff. bellottii: Uruguay: ZVC-P 876, 61, 24.5-48.4 mm SL (19 C\&S). Austrolebias charrua: Uruguay. ZVC-P 3882, 11, 32.4-35.0 mm SL (4C\&S); ZVC-P 3883, 16, 34.5-41.0 mm SL (4C\&S); ZVC-P 3884, 6, 32.1-37.9 mm SL; ZVC-P 3885, 4, 21.4-34.2 mm SL; ZVC-P 3948, 15, 31.1-36.0 mm SL (4C\&S); ZVC-P 3886, 16, 32.1-35.1 mm SL (4C\&S); ZVC-P 3911, 15, 29.8-34.1 mm SL (4C\&S); ZVC-P 3947, 15, 38.4-42.1 mm SL; ZVC-P 3944, 20, 34.9-45.0 mm SL (4C\&S). Austrolebias cheradophilus: Uruguay: ZVC-P 518, 1, $52.3 \mathrm{~mm}$ SL; ZVC-P 4283, 1, 49.9 mm SL; ZVC-P 2584, 1, 48.9 mm SL; ZVC-P 4282, 3, 45.8-54.9 mm SL (1C\&S); ZVC-P 4287, 5, 40.5$48.9 \mathrm{~mm}$ SL (3C\&S). Austrolebias cinereus: Uruguay; ZVC-P 658, 6, 24.5-38.1 mm SL (3C\&S); ZVC-P 797, 14, 29.8-34.1 mm SL. Austrolebias elongatus: Argentina: ZVC-P 713, 6, 52.4-68.1 mm SL (2C\&S); Uruguay: ZVC-P 12478, 3, 56.1-68.4 mm SL. Austrolebias juanlangi: Uruguay: ZVC-P 4310, 6, 28.9-36.5 mm SL; ZVC-P 4311, 4, 30.1-32.5 mm SL; ZVC-P 4313, 10, 25.9$38.2 \mathrm{~mm}$ SL.Austrolebias duraznensis: Uruguay: ZVC-P 4303 8, 34.1-42.6 mm SL (2C\&S). Austrolebias luteoflammulatus: Uruguay: ZVC-P 4077 20, 35.1-37.8 mm SL (4C\&S); ZVC-P 4101, 20, 22.3-33.9 mm SL (4C\&S). Austrolebias gymnoventris: ZVC-P 4318, 2, 227.3-28.3 mm SL (1C\&S); ZVC-P 4319, 2, 22.625.4 mm SL (1C\&S). Austrolebias melanoorus: Uruguay: ZVC-P 4320 16, 38.4-45.2 mm SL; ZVC-P 4322, 10, 32.4-45.0 mm SL (2 C\&S); ZVC-P 4323, 10, 34.2-47.1 mm SL (2C\&S); ZVC-P 4325, 2, 32.1-35.0 mm SL. Austrolebias nigripinnis: Paraguay: UMMZ 207493, 30, 24.1-26.9 mm SL; UMMZ 207494, 4, 23.1-32.5 mm SL; Argentina: ZVC-P 718 3, 24.5-28.9 mm SL; Uruguay: ZVC-P 848, 6, 24.6-29.9 mm SL (2C\&S). Austrolebias prognathus: Uruguay: ZVC-P 4273, 1, $56.1 \mathrm{~mm}$ SL; ZVC-P 4274 3, 49.959.4 mm SL (2C\&S); ZVC-P 4275, 2, 58.6-59.3 mm SL (1C\&S). Austrolebias quirogai: Uruguay: ZCV-P 9758 (Holotype), 36.8 mm SL; ZVC-P 8725, 69, 21.0-38.2 mm SL (5C\&S). Austrolebias reicherti: Uruguay: ZVC-P 4362, 1, 25.5-34.2 mm SL; ZVC-P 4363, 18, 30.1-40.2 mm SL (9 C\&S). Austrolebias vandenbergi: Paraguay: ANSP 175281, 3, 34.5-367 mm SL; ANSP 175282, 16, 34.6-40.1 mm SL (5C\&S). Austrolebias vazferreirai: Uruguay: ZVC-P 4289 1, 54.1 mm SL; ZVC-P 4290 4, 35.6-58.1 mm SL (2C\&S); ZVC-P 4295, 6, 42.1-61.0 mm SL (2C\&S). Austrolebias viarius: Uruguay: ZVC-P 525, 50, 30.1-42.5 mm SL (8 C\&S). Austrolebias wolterstorff: Brazil: UMMZ 181684 25, 35.1-58.3 mm SL (3C\&S); ZVC-P 3694 4, 50.1-52.3 mm SL (2C\&S); Uruguay: ZVC-P 901, 1, 57.8 mm SL; ZVC-P 4277, 8, 42.1-53.5 mm SL (4C\&S). Cynopoecilus melanotaenia: Brazil: ZVC-P 528 6, 23.5-29.9 mm SL (2C\&S); Uruguay: ZVC-P 3946, 2, 29.8$35.1 \mathrm{~mm}$ SL. Papiliolebias bitteri: Paraguay: ANSP 170422 19, 25.5-30.1 mm SL; ZVC-P 2766, 20, 23.4-32.1 mm SL (5C\&S). Simpsonichthys chacoensis: Paraguay: ANSP 170272, 3, 23.5$28.9 \mathrm{~mm}$ SL (1C\&S); ANSP 170273, 2, 23.5-28.0 mm SL.

\section{Acknowledgments}

We are grateful to Luiz Malabarba and Juliano Ferrer for their help in the field trips in Rio Grande do Sul (Brazil); to José Bessonart, Sofía Stareczek, and Matías Zarucki for their help in the field trips in Uruguay; to William Crampton, James Albert, and an anonymous reviewer for their comments and corrections which improved the quality of the manuscript; to Andrew Thompson and Edward Burress for the language corrections and suggestions.

\section{References}

Ab'Saber AN. Participação das superfícies aplainadas nas paisagens do Rio Grande do Sul. Geomorfologia. 1969; (11):1-15.

Alonso F, Terán GE, Calviño P, García I, Cardoso Y, García G. An endangered new species of seasonal killifish of the genus Austrolebias (Cyprinodontiformes: Aplocheiloidei) from the Bermejo river basin in the Western Chacoan Region. PLoS ONE [serial on the Internet]. 2018; 13(5):e0196261. Available from: https://doi.org/10.1371/journal.pone.0196261

Altner M, Reichenbacher B. †Kenyaichthyidae fam. nov. and $\dagger$ Kenyaichthys gen. nov.: First Record of a Fossil Aplocheiloid Killifish (Teleostei, Cyprinodontiformes). PLoS ONE [serial on the Internet]. 2015; 10(4):e0123056. Available from: http:// dx.doi.org/10.1371/journal.pone.0123056

Arim M, Abades SR, Laufer G, Loureiro M, Marquet PA. Food web structure and body size: Trophic position and resource acquisition. Oikos. 2010; 119(1):147-53.

Avise JC, Tatarenkov A. Population genetics and evolution of the mangrove rivulid Kryptolebias marmoratus, the world's only self-fertilizing hermaphroditic vertebrate. J Fish Biol. 2015; 87(3):519-38.

Ayup-Zouain RN. Evolución paleogeográfica y dispersión de los sedimentos del Río de la Plata. In: Menafra R, RodríguezGallego L, Scarabino F, Conde D, editores. Bases para la conservación y el manejo de la costa uruguaya. Montevideo: Vida Silvestre Uruguay; 2006. p.1-8. 
Belote DF, Costa WJEM. Reproductive behavior of the Brazilian annual fish Cynolebias albipunctatus Costa and Brasil, 1991 (Teleostei, Cyprinodontiformes, Rivulidae): a new report of sound production in fishes. Arq Mus Nac. 2003; 61(4):241-44.

Berois N, Arezo MJ, Papa NG, Chalar C. Life cycle, reproduction, and development in annual fishes: Cellular and molecular aspects. In: Berois N, García G, de Sá RO, editors. Annual Fishes: life history strategy, diversity, and evolution. Boca Ratón: CRC Press; 2016. p.33-46.

Bertaco VA, Ferrer J, Carvalho FR, Malabarba LR. Inventory of the freshwater fishes from a densely collected area in South America - a case study of the current knowledge of Neotropical fish diversity. Zootaxa. 2016; 4138(3):401-40.

Bishop P. Drainage rearrangement by river capture, beheading and diversion. Prog Phys Geogr. 1995; 19(4):449-73.

Blažek R, Polačik M, Reichard M. Rapid growth, early maturation and short generation time in African annual fishes. EvoDevo [serial on the Internet]. 2013; 4:24. Available from: https://doi. org/10.1186/2041-9139-4-24

Calviño P. Austrolebias toba (Cyprinodontiformes: Rivulidae), una especie nueva de pez anual de la Argentina. Rev Mus Argent Cienc Nat. 2005; 7(2):183-90.

Casanova-Larrosa G, Rosillo JC, Olivera-Bravo S, Fernández AS. Comparative anatomy and proliferative zones of adult Austrolebias brain. In: Berois N, García G, de Sá RO, editors. Annual Fishes: life history strategy, diversity, and evolution. Boca Ratón: CRC Press; 2016. p.231-250.

Costa WJEM. Análise filogenética da família Rivulidae (Cyprinodontiformes, Aplocheiloidei). Rev Bras Biol. 1990; 50:65-82.

Costa WJEM. Pearl killifishes: The Cynolebiatinae: Systematics and biogeography of the Neotropical annual fish subfamily. Neptune City: TFH; 1995.

Costa WJEM. Phylogeny and classification of Rivulidae revisited: Origin and evolution of annualism and miniaturization in rivulid fishes (Cyprinodontiformes: Aplocheiloidei). J Comp Biol. 1998; 3:33-94.

Costa WJEM. Monophyly and phylogenetic relationships of the neotropical annual fish genera Austrolebias and Megalebias (Cyprinodontiformes: Rivulidae). Copeia. 2002a; (4):916-27.

Costa WJEM. The Austrolebias alexandri species group: a taxonomical revision of an annual fish clade (Cyprinodontiformes: Rivulidae) in southern Brazil. Com Mus Cien PUCRS. 2002b; 15:87-111.

Costa WEJM. Relationships and redescription of Fundulus brasiliensis (Cyprinodontiformes: Rivulidae), with description of a new genus and notes on the classification of the Aplocheiloidei. Ichthyol Explor Freshw. 2004a; 15(2):105-20.

Costa WEJM. A new killifish genus and species from the coastal plains of northeastern Brazil (Teleostei: Cyprinodontiformes: Rivulidae). Zootaxa. 2004b; 642(1):1-10.

Costa WEJM. Relationships and taxonomy of the killifish genus Rivulus (Cyprinodontiformes: Aplocheiloidei: Rivulidae) from the Brazilian Amazonas river basin, with notes on historical ecology. Aqua. 2006a; 11(4):133-45.

Costa WJEM. The South American annual killifish genus Austrolebias (Teleostei: Cyprinodontiformes: Rivulidae): Phylogenetic relationships, descriptive morphology and taxonomic revision. Zootaxa. 2006b; 1213:1-162.
Costa WJEM. Monophyly and taxonomy of the Neotropical seasonal killifish genus Leptolebias (Teleostei: Aplocheiloidei: Rivulidae), with the description of a new genus. Zool J Linn Soc. 2008a; 153(1):147-60.

Costa WJEM. Catalog of Aplocheiloid killifishes of the World. Rio de Janeiro: Universidade Federal do Rio de Janeiro; 2008b.

Costa WJEM. Historical biogeography of Cynolebiasine annual killifishes inferred from dispersal-vicariance analysis. J Biogeogr. 2010; 37(10):1995-2004.

Costa WJEM. Phylogenetic position and taxonomic status of Anablepsoides, Atlantirivulus, Cynodonichthys, Laimosemion, and Melanorivulus (Cyprinodontiformes: Rivulidae). Ichthyol Explor Freshw. 2011a; 22(3):233-49.

Costa WJEM. Comparative morphology, phylogenetic relationships, and historical biogeography of Plesiolebiasine seasonal killifishes (Teleostei: Cyprinodontiformes: Rivulidae). Zool J Linn Soc. 2011b; 162(1):131-48.

Costa WJEM. Delimiting priorities while biodiversity is lost: Rio's seasonal killifishes on the edge of survival. Biodivers Conserv. 2012; 21(10):2443-52.

Costa WEJM. Historical biogeography of Aplocheiloid killifishes (Teleostei: Cyprinodontiformes). Vertebr Zool. 2013; 63(2):139-54.

Costa WJEM. A new genus of miniature Cynolebiasine from the Atlantic Forest and alternative biogeographical explanations for seasonal killifish distribution patterns in South America (Cyprinodontiformes: Rivulidae). Vertebr Zool. 2014a; 64(1):23-33.

Costa WEJM. Phylogeny and evolutionary radiation in seasonal rachovine killifishes: Biogeographical and taxonomical implications. Vertebr Zool. 2014b; 64(2):177-92.

Costa WJEM. Austrolebias araucarianus, a new seasonal killifish from the Iguaçu river drainage, southern Brazilian Araucarian Plateau Forest (Cyprinodontiformes: Rivulidae). Ichthyol Explor Freshw. 2014c; 25(2):97-101.

Costa WJEM. Comparative morphology and classification of South American Cynopoeciline killifishes (Cyprinodontiformes: Aplocheilidae), with notes on family-group names used for aplocheiloids. Vertebr Zool. 2016a; 66(2):125-40.

Costa WJEM. Inferring evolution of habitat usage and body size in endangered, seasonal Cynopoeciline killifishes from the South American Atlantic Forest through an integrative approach (Cyprinodontiformes: Rivulidae). PLoS One [serial on the Internet]. 2016b; 11(7):e0159315. Available from: http://dx.doi.org/10.1371/journal.pone.0159315.

Costa WJEM, Amorim PF, Mattos JLO. Molecular phylogeny and evolution of internal fertilization in South American seasonal Cynopoeciline killifishes. Mol Phylogenet Evol [serial on the Internet]. 2015; 95:94-99. Available from: http://dx.doi. org/10.1016/j.ympev.2015.11.011

Costa WJEM, Amorim PF, Mattos JLO. A new species of inseminating seasonal killifish of the Cynopoecilus melanotaenia complex from southern Brazil (Cyprinodontiformes: Rivulidae). 2016. Biodiversity Data Journal 4: e6888 doi: 10.3897/BDJ.4.e6888.

Costa WJEM, Amorim PF, Mattos JLO. Molecular phylogeny and timing of diversification in South American Cynolebiini seasonal killifishes. Mol Phylogenet Evol [serial on the Internet]. 2017a; 116:61-68. Available from: http://dx.doi. org/10.1016/j.ympev.2017.07.020 
Costa WJEM, Amorim PF, Mattos JLO. Synchronic historical patterns of species diversification in seasonal aplocheiloid killifishes of the semi-arid Brazilian Caatinga. PLoS ONE [serial on the Internet]. 2018; 13(2):e0193021. https://dx.doi. org/10.1371/journal.pone.0193021

Costa WJEM, Cheffe MM, Amorim PF. Two new seasonal killifishes of the Austrolebias adloffi group from the Lagoa dos Patos basin, southern Brazil (Cyprinodontiformes: Aplocheilidae). Vertebr Zool. 2017b; 67(2):139-49.

Costa WJEM, Lima SMQ, Bartolette R. Androdioecy in Kryptolebias killifish and the evolution of self-fertilizing hermaphroditism. Biol J Linn Soc. 2010; 99(2):344-49.

Errea A, Danulat E. Growth of the annual fish, Cynolebias viarius (Cyprinodontiformes), in the natural habitat compared to laboratory conditions. Environ Biol Fishes. 2001; 61(3):261-68.

Eschmeyer WN, Fricke R, van der Laan R, editors. Catalog of fishes: genera, species, references [Internet]. San Francisco: California Academy of Science; 2018 [updated 2018 Jan 15; cited 2018 Jan 18]. Available from: http://researcharchive.calacademy.org/ research/ichthyology/catalog/fishcatmain.asp

Ferrer J, Malabarba LR, Costa WJEM. Austrolebias paucisquama (Cyprinodontiformes: Rivulidae), a new species of annual killifish from southern Brazil. Neotrop Ichthyol. 2008; 6(2):175-80.

Ferrer J, Wingert JM, Malabarba LR. Description of a new species and phylogenetic analysis of the subtribe Cynopoecilina, including continuous characters without discretization (Cyprinodontiformes: Rivulidae). Zool J Linn Soc. 2014; 172(4):846-66.

Friedman M, Keck BP, Dornburg A, Eytan RI, Martin CH, Hulsey CD, Wainwright PC, Near TJ. Molecular and fossil evidence place the origin of cichlid fishes long after Gondwanan rifting. Proc R Soc B Biol Sci [serial on the Internet]. 2013; 280(1770):20131733. Available from: http://dx.doi.org/10.1098/ rspb.2013.1733

Furness AI, Reznick DN, Springer MS, Meredith RW. Convergent evolution of alternative developmental trajectories associated with diapause in African and South American killifish. Proc R Soc B Biol Sci. 2015; 282(1802):20142189.

Furness AI, Reznick DN, Tatarenkov A, Avise JC. The evolution of diapause in Rivulus (Laimosemion). Zool J Linnean Soc [serial on the Internet]. 2018; 20:1-18. Available from: http://dx.doi. org/10.1093/zoolinnean/zly021

FZBRS. Reavaliação da lista das espécies da fauna silvestre ameaçadas de extinção no Rio Grande do Sul. 2014. Available from: http://www.fzb.rs.gov.br/ upload/2014090911580809_09_2014_especies_ameacadas. pdfAcessed in September 2018.

García G. Multiple simultaneous speciation in killifishes of the Cynolebias adloffi species complex (Cyprinodontiformes, Rivulidae) from phylogeography and chromosome data. J Zool Syst Evol Res. 2006; 44(1):75-87.

García G, Gutiérrez V, Ríos N, Turner B, Santiñaque F, LópezCarro B, Folle G. Burst speciation processes and genomic expansion in the neotropical annual killifish genus Austrolebias (Cyprinodontiformes, Rivulidae). Genetica. 2014; 142(1):87-98.

García G, Gutiérrez V, Vergara J, Calviño P, Duarte A, Loureiro M. Patterns of population differentiation in annual killifishes from the Paraná-Uruguay-La Plata Basin: The role of vicariance and dispersal. J Biogeogr. 2012; 39(9):1707-19.
García G, Loureiro M, Berois N, Arezo MJ, Casanova G, Clivio G, Olivera A. Pattern of differentiation in the annual killifish genus Austrolebias (Cyprinodontiformes: Rivulidae) from a biosphere reserve site in South America: a multidisciplinary approach. Biol J Linn Soc. 2009; 98(3):620-35.

García D, Loureiro M, Tassino B. Reproductive behavior in the fish Austrolebias reicherti Loureiro and García 2004 (Cyprinodontiformes: Rivulidae). Neotrop Ichthyol. 2008; 6(2):243-48.

Genner MJ, Seehausen O, Lunt DH, Joyce DA, Shaw PW, Carvalho GR, Turner GF. Age of cichlids: new dates for ancient lake fish radiations. Mol Biol Evol. 2007; 24(5):1269-82.

Haas R. Sexual selection in Nothobranchius guentheri (Pisces: Cyprinodontidae). Evolution. 1976; 30(3):614-22.

Hertwig T. Phylogeny of the Cyprinodontiformes (Teleostei, Atherinomorpha): The contribution of cranial soft tissue characters. Zool Scr. 2008; 37(2):141-74.

Hrbek T, Deus CP, Farias IP. Rivulus duckensis (Teleostei; Cyprinodontiformes): New species from the Tarumã basin of Manaus, Amazonas, Brazil, and its relationships to other Neotropical Rivulidae. Copeia. 2004; (3):569-76.

Hrbek T, Larson A. The evolution of diapause in the killifish family Rivulidae (Atherinomorpha Atherinomorpha, Cyprinodontiformes): A molecular phylogenetic and biogeographic perspective. Evolution. 1999; 53(4):1200-16.

Hrbek T, Taphorn DC. Description of a new annual rivulid killifish genus from Venezuela. Zootaxa. 2008. 1734:27-42.

International Commission on Zoological Nomenclature. International Code of Zoological Nomenclature, 4th Edition. 1999. The International Trust for Zoological Nomenclature, London, xxix + 306 pp.http://dx.doi.org/10.5962/bhl. title.50608

International Union for Conservation of Nature (IUCN). Red List of Threatened Species. Version 2017-3 [Internet]. 2017. Available from: www.iucnredlist.org

van der Laan R, Eschmeyer W, Fricke, R. Family-group names of recent fishes. Zootaxa. 2014; 3882(2):1-230.

LiC, Ortí G, Zhang G, Lu G.Apractical approach to phylogenomics: the phylogeny of ray-finned fish (Actinopterygii) as a case study. BMC Evol Biol [serial on the Internet]. 2007; 7:44. Available from: https:/dx.doi.org/10.1186/1471-2148-7-44

Loureiro M. Sistemática y Biogeografía de los Peces Anuales de la Subtribu Cynolebiatina (Cyprinodontiformes: Rivulidae: Cynolebiatinae). [ PhD Thesis]. Montevideo: Universidad de la República (Uruguay), Facultad de Ciencias, PEDECIBA; 2004.

Loureiro M, Borthagaray A, Hernández D, Duarte A, Pinelli V, Arim M. Austrolebias in space: scaling from ponds to biogeographical regions. In: Berois N, García G, de Sá RO, editors. Annual Fishes: life history strategy, diversity, and evolution. Boca Ratón: CRC Press; 2016. p.111-132.

Loureiro M, Duarte A, Zarucki M. A new species of Austrolebias Costa (Cyprinodontiformes: Rivulidae) from northeastern Uruguay, with comments on distribution patterns. Neotrop Ichthyol. 2011; 9(2):335-42.

Loureiro M, García G. Austrolebias reicherti Loureiro \& García, a valid species of annual fish (Cyprinodontiformes: Rivulidae) from Uruguay. Zootaxa. 2008; 1940:1-15. 
Loureiro M, de Sá RO. Diversity of Aplocheiloidei. In: Berois N, García G, de Sá RO, editors. Annual Fishes: life history strategy, diversity, and evolution. Boca Ratón: CRC Press; 2016. p.3-32.

Malabarba LR, Malabarba MC, Reis RE. Descriptions of five new species of the Neotropical cichlid genus Gymnogeophagus Miranda Ribeiro, 1918 (Teleostei: Cichliformes) from the rio Uruguay drainage. Neotrop Ichthyol. 2015; 13(4):637-62.

Marques AAB, Fontana CS, Velez E, Bencke GA, Schneider M, Reis RE. Lista de Referência da Fauna Ameaçada de Extinção no Rio Grande do Sul. Decreto no 41.672, de 11 junho de 2002. Porto Alegre: FZB/MCT-PUCRS/PANGEA; 2002.

Matschiner M, Musilová Z, Barth JMI, Starostová Z, Salzburger W, Steel M, Bouckaert R. Bayesian phylogenetic estimation of clade ages supports Trans-Atlantic dispersal of cichlid fishes. Syst Biol. 2017; 66(1):3-22.

McMahan CD, Chakrabarty P, Sparks JS, Smith WL, Davis MP. Temporal patterns of diversification across global cichlid biodiversity (Acanthomorpha: Cichlidae). PLoS One [serial on the Internet]. 2013; 8(8):e71162. Available from: https://dx.doi. org/10.1371/journal.pone.0071162

Murphy WJ, Collier GE. Phylogenetic relationships within the aplocheiloid fish genus Rivulus (Cyprinodontiformes, Rivulidae): Implications for Caribbean and Central American biogeography. Mol Biol Evol. 1996; 13(5):642-49.

Murphy WJ, Collier GE. A molecular phylogeny for aplocheiloid fishes (Atherinomorpha, Cyprinodontiformes): The role of vicariance and the origins of annualism. Mol Biol Evol. 1997; 14(8):790-99.

Murphy WJ, Thomerson, JE, Collier GE. Phylogeny of the Neotropical killifish family Rivulidae (Cyprinodontiformes, Aplocheiloidei) inferred from mitochondrial DNA sequences. Mol Phylogenet Evol. 1999; 13(2):289-301.

Myers GS. Results of some recent studies on the American killifishes. Fish Culturist. 1925; 4:370-71.

Nascimento WS, Yamamoto ME, Chellappa NT, Rocha O, Chellappa, S. Conservation status of an endangered annual fish Hypsolebias antenori (Rivulidae) from Northeastern Brazil. Braz J Biol. 2015; 75(2):484-90.

Near TJ, Eytan RI, Dornburg A, Kuhn KL, Moore JA, Davis MP, Wainwright PC, Friedman M, Smith WL. Resolution of rayfinned fish phylogeny and timing of diversification. Proc Natl Acad Sci USA. 2012; 109(34):13698-703.

Palumbi S, Martin A, Romano S, McMillan WO, Stice L, Grabowski G. The simple fool's guide to PCR. Honolulu: Department of Zoology and Kewalo Marine Laboratory, Univ. Hawaii; 1991.

Parenti LR. A phylogenetic and biogeographic analysis of Cyprinodontiform fishes (Teleostei: Atherinomorpha). Bull Am Mus Nat Hist. 1981; 168(4):341-557.

Passos C, Tassino B, Loureiro M, Rosenthal GG. Intra- and intersexual selection on male body size in the annual killifish Austrolebias charrua. Behav Processes. 2013; 96:20-26.

Perujo E, Calviño PA, Salvia H, Prieto F. Austrolebias luzardoi (Cyprinodontiformes: Rivulidae), una especie nueva de pez anual de la cuenca del río Cuareim, República Oriental del Uruguay. Rev Mus La Plata, Secc Zool. 2005; 17(171):1-12.

Podrabsky JE, Romney AL, Culpepper KM. Alternative Developmental Pathways. In: Berois N, García G, de Sá RO, editors. Annual Fishes: life history strategy, diversity, and evolution. Boca Ratón: CRC Press,; 2016. p.63-74.
Pohl M, Milvertz FC, Meyer A, Vences M. Multigene phylogeny of Cyprinodontiform fishes suggests continental rediations and a rogue táxon position of Pantanodon. Vertebr Zool. 2015; 65(1):37-44.

Ponce de León JL, León G, Rodríguez R, Metcalfe CJ, Hernández D, Casane D, García-Machado E. Phylogeography of Cuban Rivulus: Evidence for allopatric speciation and secondary dispersal across a marine barrier. Mol Phylogenet Evol. 2014; 79:404-14.

Ponzetto JM, Britzke R, Nielsen DTB, Parise-Maltempi PP, Alves AL. Phylogenetic relationships of Simpsonichthys subgenera (Cyprinodontiformes, Rivulidae), including a proposal for a new genus. Zool Scr. 2016; 45(4):394-406.

Reichard M. The evolutionary ecology of African annual fishes. In: Berois N, García G, de Sá RO, editors. Annual fishes: life history strategy, diversity, and evolution. Boca Ratón: CRC Press; 2016. p.133-158.

Ronquist F. Dispersal-vicariance analysis: a new approach to the quantification of historical biogeography. Syst Biol. 1997; 46(1):195-203.

Sprechmann P. The paleoecology, paleogeography and stratigraphy of the Uruguayan coastal area during the Neogene and Quaternary. Zitteliana. 1978; 4:3-72.

Steindachner F. Ichthyologische Beiträge (V) - III Über einige Meeresfische von den Kusten Brasiliens. Sitzungsberichte der Kaiserlichen Akademie der Wissenschaften in Wien, Abteilung 1, Mathematische-naturwissenschaftliche Klasse. $1876 ; 74: 49-240$.

Tatarenkov A, Lima SMQ, Avise JC. Extreme homogeneity and low genetic diversity in Kryptolebias ocellatus from south-eastern Brazil suggest a recent foundation for this androdioecious fish population. J Fish Biol. 2011; 79(7):2095-105.

Thompson AW, Furness AI, Stone C, Rade CM, Ortí G. Microanatomical diversification of the zona pellucida in Aplochelioid killifishes. J Fish Biol. 2017; 91(1):126-43.

Vermeulen FBN, Hrbek T. Kryptolebias sepia n. sp. (Actinopterygii: Cyprinodontiformes: Rivulidae), a new killifish from the Tapanahony River drainage in southeast Surinam. Zootaxa. 2005; 928(1):1-20.

Volcan MV, Gonçalves AC, Lanés LEK, Guadagnin DL. Annual Fishes (Rivulidae) from Southern Brazil: A Broad-Scale Assessment of Their Diversity and Conservation. In: Berois N, García G, de Sá RO, editors. Annual Fishes: life history strategy, diversity, and evolution. Boca Ratón: CRC Press; 2016. p.185-203.

Volcan MV, Gonçalves AC, Lanés LEK. A new annual fish of the genus Austrolebias (Cyprinodontiformes: Rivulidae) from Rio Camaquã basin, Laguna dos Patos system, Brazilian Pampa. Zootaxa. 2017; 4338(1):141-52.

Wourms JP. The developmental biology of annual fishes. III. Preembryonic and embryonic diapause of variable duration in the eggs of annual fishes. J Exp Zool. 1972; 182(3):389-414. 